\title{
The changing landscape of accrual accounting
}

\author{
Robert M. Bushman \\ University of North Carolina at Chapel Hill \\ Robert_Bushman@kenan-flagler.unc.edu
}

\author{
Alina Lerman \\ Yale University \\ alina.lerman@yale.edu \\ X. Frank Zhang \\ Yale University \\ frank.zhang@yale.edu
}

July 2015

* We thank Ted Christensen, Ilia Dichev, Greg Miller, and workshop participants at Florida International University, Fordham University, Fudan University, Peking University, Tsinghua University, University of Chicago, and University of Michigan for helpful suggestions and comments. We also acknowledge financial support from Yale University. 


\title{
The changing landscape of accrual accounting
}

\begin{abstract}
A fundamental property of accrual accounting is to smooth temporary timing fluctuations in operating cash flows, indicating an inherent negative correlation between accruals and cash flows. We show that the overall correlation between accruals and cash flows has dramatically declined in magnitude over the past half century and has largely disappeared in more recent years. The adjusted $\mathrm{R}^{2}$ from regressing (changes in) accruals on (changes in) cash flows drops from about $70 \%(90 \%)$ in the 1960 s to near zero (under $20 \%$ ) in more recent years. In exploring potential reasons for the observed attenuation, we find that increases in non-timing-related accrual recognition, as proxied by one-time and non-operating items and the frequency of loss firm-years, explain the majority of the overall decline. On the other hand, temporal changes in the matching between revenues and expenses, and the growth of intangible-intensive industries play only a limited role in explaining the observed attenuation. Lastly, the relative decline of the timing role of accruals does not appear to be associated with an increase in the asymmetrically timely loss recognition role.
\end{abstract}

Keywords: accrual accounting, accruals, cash flows, earnings management, accrual quality

JEL: M40, M41, G12, G14 


\section{Introduction}

A central role of accrual accounting is to smooth out temporary fluctuations in cash flows (e.g., Dechow 1994; Dechow et al. 1998), as accrual accounting systems recognize economic events in firms' financial statements independently of the timing of cash flows associated with these events. We refer to this role as the timing role (or the smoothing or noise reduction role) of accruals. By adding accruals to operating cash flows, accrual accounting systems produce an earnings number that should be a less noisy measure of operating performance than operating cash flows. As Dechow (1994) points out, a central implication of the timing role of accrual accounting is that contemporaneous accruals and cash flows are negatively correlated. This negative correlation is often taken as given in the literature and serves as the cornerstone of a variety of earnings/accrual quality models (e.g., Dechow and Dichev 2002). In this paper, we show that the correlation between accruals and cash flows has dramatically diminished in magnitude over the past half century and has largely disappeared in more recent years.

We adopt two models to examine the overall correlation between accruals and cash flows. The first one is based on Dechow (1994) and regresses total accruals on contemporaneous operating cash flows. We run the model both in levels and in changes specifications for each year from 1964 through 2014 and examine the temporal change in the goodness of fit measure and in the coefficient on contemporaneous cash flows. We find that the adjusted $\mathrm{R}^{2}$ drops from about $70 \%$ (90\%) in the 1960 s to near zero (under 20\%) in more recent years for the levels (changes) specification. At the same time, the negative coefficient on contemporaneous cash flows experiences a drastic increase over the years. Under the levels (changes) specification, an increase of $\$ 1$ in operating cash flows was associated with a decrease of approximately 70 cents (90 cents) in accruals in 1960s, but the effect on accruals dropped to under 10 cents (about 50 
cents) in the last ten years. The results suggest that the overall correlation between accruals and cash flows has significantly diminished over the past fifty years in a persistent and smooth manner.

The second model we use is the Dechow and Dichev (2002) regression of total accruals on past, current, and future operating cash flows. Again, we find a dramatic decline in the adjusted $\mathrm{R}^{2}$ of the model and a smooth increase in the coefficient on contemporaneous cash flows over the fifty-year period. The adjusted $\mathrm{R}^{2}$ has dropped from about $70 \%$ in the 1960 s to below $10 \%$ in the latest years, whereas the coefficient on contemporaneous cash flows has increased from about -0.8 to -0.4 over the same time period. In contrast, the coefficients on past and future cash flows show only a small positive change in magnitude over time. While we use the balance sheet approach to estimate total accruals for the early years of the sample and the statement of cash flows approach from 1988 forward, we observe a similar pattern of decline when carrying out our analysis with the balance sheet approach on the full sample for consistency.

Having documented the pronounced and continuous decline in the overall correlation between accruals and cash flows, we explore potential reasons for this attenuation. A number of economic and accounting developments could be associated with this decline. For example, if cash flows and economic earnings have become more volatile, reflecting increasing economic shocks to firms' operations, then accruals are likely to have a weaker correlation with cash flows in the later years. A temporal increase in the frequency of reported non-recurring and nonoperating items and net losses may also contribute to the attenuation of the negative correlation both because these items are not often accompanied by large positive cash flows and because the accruals made in response to the underlying negative shocks are likely to involve significant 
estimation error. The growing prominence of firms with high intangible intensity could lead to an increase in transactions which do not generate accruals due to immediate expensing of cash outflows. Accruals may also increasingly reflect the timely loss recognition role, which suggests a positive correlation between accruals and cash flows and thus attenuate the overall negative correlation. From the accounting standards perspective, the FASB's expansion of the balance sheet-based model of financial reporting, in such manifestations as the push toward fair value accounting, may have made accruals less correlated with cash flows overall (without necessarily increasing the amount of estimation errors in the accrual generating process). Overall, even though the conceptual timing role of accrual accounting has not been changed, a significant increase in the magnitude of other elements of accruals (e.g., economic-based cash flow shocks, accrual estimation errors, fair value adjustments, one-time and non-operating items, timely loss recognition, losses and earnings management) may lead to a decline in the extent of the observed negative correlation between accruals and operating cash flows. ${ }^{1}$

We find that increases in one-time and non-operating items and in firms reporting losses, all of which are proxies for non-timing-related accrual recognition, are positively associated with the attenuation in the timing role of accrual accounting. Collectively, they explain about $63 \%$ of the decline in the overall correlation between accruals and cash flows. On the other hand, the changes in economic-based cash flow shocks, the temporal changes in the matching between revenues and expenses (Dichev and Tang 2008), the emergence of intangible-intensive firms (Srivastava 2014), and in the asymmetrically timely recognition of gains and losses (Ball and Shivakumar 2006) play only a limited role. Overall, it appears that the decline in the relative prominence of the timing role is an artifact of changing operating uncertainty and accounting

\footnotetext{
${ }^{1}$ There may be other reasons, not addressed in this paper, why accruals are increasingly representative of estimation errors or corrections of prior estimation errors which do not map into cash flows, including temporal changes in earnings management.
} 
practices that have increased the presence of non-timing-related accruals and the frequency of loss years.

We perform a battery of additional tests to extend the main results. First, we examine the relationship between accruals and cash flows using firm-specific time-series regressions and observe that the results corroborate those from cross-sectional regressions. Next, we follow Srivastava (2014) and examine separately five successive listing cohorts. We document the temporal attenuation in the accrual-cash flow relationship for all cohorts. To further explore the potential effects of the change in the sample composition over time we repeat our analyses on a sample of the largest 1,000 firms in each year and on relatively constant samples of firms with at least 30 (40) years of data. We also consider a broad definition of accruals in Richardson et al. (2005) and find the tenor of the paper unchanged. Next, we expand the smoothing window to non-adjacent fiscal periods to consider the possibility that accruals map to cash flows up to three periods preceding and following the current period. Finally, we consider whether changes in operating cash cycles, changes in absolute total accruals, or industry effects contribute to the observed attenuation. Overall, we find that our results are robust to these alternative samples and specifications.

Our evidence that the overall correlation between accruals and cash flows has significantly declined over the years has broad implications for academics, practitioners, and regulators. Given that the accounting rules governing the basic recognition of revenues and expenses have, in large part, remained unchanged, fundamentally the basic role of accruals is still smoothing out the temporary fluctuations in cash flows. However, both economic and reporting developments have led to the dramatic decline in the relative prominence of this timing role. The growth in the frequency and the magnitude of non-timing accruals has increasingly 
obscured the expected negative accrual-cash flow relation. Accounting educators and practitioners should be interested in the magnitude of the decline and the explanatory factors for it which may help identify firms or periods where it is particularly likely to be observed. Despite the unchanged conceptual timing role of accruals, it is important to note that empirically today's accruals contribute little towards reducing earnings volatility relative to cash flow volatility. Practitioners and academics may want to revisit the notion that a negative relationship between accruals and cash flows is a necessary characteristic of high-quality earnings (e.g., Dechow and Dichev 2002; Dichev et al. 2013). Finally, existing research has documented that many accrual related regularities, such as value relevance of earnings and the accrual anomaly, have declined over time (Collins et al. 1997; Green et al. 2011). It is possible that our documented attenuation in the accrual cash flow relation and the factors contributing to that attenuation may be able to explain, in full or in part, these observed phenomena.

On a more pragmatic note, the Dechow and Dichev (2002) measure of accrual mapping into cash flows and its various modifications are ubiquitous in the accounting research literature. The characteristics of their empirical results, such as the reported adjusted $R^{2}$ of $47 \%$ from the firm level analysis, are widely discussed and at times used as points of reference for similar models (Dechow et al. 2010). Empirical accounting studies, which either examine accrual accounting or utilize measures of accrual quality, typically pool historical data over the full sample, by industry, or by firm, in examining their research questions. The decline in the inherent relationship between contemporaneous accruals and operating cash flows suggests that researchers should be aware of the possible inter-temporal changes in this measure and, at a minimum, should evaluate the consistency of their findings over time. ${ }^{2}$ For example, we

\footnotetext{
${ }^{2}$ The documented attenuation in the accrual-cash flow relation is particularly relevant for studies which utilize the Dechow and Dichev model or its modification on a more recent time-period (e.g. McInnis and Collins 2011 for the
} 
document that the magnitude and standard deviation of residual accruals calculated from either the firm-specific or the pooled specifications of the Dechow (1994) or the Dechow and Dichev (2002) models are systematically underestimated in the more recent years. Another implication of our findings that popular accrual models lack explanatory power in recent years calls the meaning of the estimation of residual accruals into question. If cash flows explain little of the variation in accruals, then the residual is basically accruals and the variance of residual accruals is equivalent to the variance of accruals, which does not seem to be a useful way to assess accounting quality. ${ }^{3}$

Our findings may also be important for studies that examine the relative change in the Dechow and Dichev or other smoothing metrics of accruals across various time periods (e.g., Singer and You 2011; Doyle and Magilke 2013). Although these papers are carefully constructed to rely on difference in difference techniques over samples matched on characteristics such as industry affiliation and size, we suggest that the explanatory factors that contribute to the attenuation of the timing relationship, such as non-recurring and non-operating items, should also be controlled for. Measures of accruals quality rooted in the negative correlation between accruals and cash flows are also increasingly applied in the examination of non-US samples (Barth et al. 2012). Our findings suggest that researchers comparing US and foreign regimes should consider whether other countries have experienced a similar decline in the accrual-cash flow relation and, if so, whether it stemmed from the same economic and reporting factors.

We organize the rest of the paper as follows. Section 2 reviews relevant literature. Sections 3 describe our sample. Section 4 presents the main empirical results and explores

sample 1994-2004; McNichols and Stubben 2014 for the sample 1990-2010; Hribar et al. 2013 for the sample 2000 to 2010 ).

${ }^{3}$ Our findings also have implications for formal modeling of the accrual process to the extent that such modeling relies on the negative correlation between contemporaneous accruals and cash flows as a base assumption in modeling other relationships (e.g. Richardson et al. 2005). 
potential explanations. Section 5 discusses robustness tests and implications, and Section 6 concludes.

\section{Prior Research and Background}

Accrual accounting recognizes economic events in firms' financial statements independently of the timing of cash flows associated with these events. ${ }^{4}$ The contrast between cash-based accounting and accrual-based accounting is highlighted in Financial Accounting Standards Board [FASB] Concept 1:

"[Accrual accounting] recognizes that the buying, producing, selling, and other operations of an enterprise during a period, as well as other events that affect enterprise performance, often do not coincide with the cash receipts and payments of the period." (paragraph 44)

A central role of accrual accounting, which we refer to as the timing role, is to smooth out temporary timing fluctuations in operating cash flows. For example, consider a firm in a steady state with constant scale of operations over time. An increase in accounts receivable due to a customer unexpectedly delaying payments would simultaneously reduce cash flows (as compared to a case of prompt payment) and increase accruals by the same amount. Similarly, a temporary increase in inventory is associated with growth in the working capital account "inventory" and a contemporaneous reduction in operating cash flows. Accrual accounting prevents such transitory fluctuations from affecting the reported earnings of the firm via accruals with similar magnitude but opposite signs to cash flows. As Dechow (1994) points out, the central prediction of the timing role of accrual accounting is that accruals and cash flows from operations are negatively correlated. This smoothing property of the reporting system can be

\footnotetext{
${ }^{4}$ We use the term "independently" to highlight the standard definition of accrual accounting as a practice of recognizing revenues when earned and expenses when incurred, without regard to the time of receipt or payment of cash (Kieso et al. 2012 p.121). We abstract from the notion that cash flows may influence the recognition of revenues and expenses under accrual accounting such as in situations when their presence or absence may indicate a diminished degree of certainty regarding the estimation of future cash flows.
} 
viewed as a channel by which accruals increase the informativeness of reported earnings. Accrual accounting systems produce an earnings number that is less noisy than operating cash flows as accruals mitigate the noise that arises from exogenous or manipulative variation in working capital items. Accruals record real economic transactions in a timely fashion, thus distinguishing our system of accounting from the mere counting of cash.

The negative contemporaneous association between operating cash flows and total accruals is observed going back to some of the early studies on accrual accounting (Rayburn, 1986; McNichols and Wilson, 1988). Rayburn (1986) records firm-specific Pearson correlation of -0.81 between the levels of cash flows from operations and total accruals in the 1962-1982 period. McNichols and Wilson (1988) observe Spearman correlation of -0.69 (-0.78) between the levels (changes) of the two variables in the 1967-1985 period. Later research continues to explore the association in a more systematic fashion. Dechow (1994), Sloan (1996), and Dechow et al. (1998) all predict, document, and exploit a negative contemporaneous correlation between levels or changes of aggregate accruals and operating cash flows. Dechow (1994), in particular, specifically posits that the negative association is inherent in the system where accruals are used to smooth the noisy cash flow metrics. This relation stems from the temporary nature of cash flow fluctuations and is smaller when measured over longer intervals. Dechow and Dichev (2002) expand on this role of accruals and introduce a measure, which they term accrual quality, capturing the mapping of current accruals into last period, current period, and next period cash flows. In line with the timing role of accrual accounting, their analysis indicates that the association between working capital accruals and contemporaneous operating cash flows is strongly negative while that between accruals and past/future cash flows is positive (albeit of a much smaller magnitude). Subsequent literature has relied heavily on the Dechow and Dichev 
(2002) mapping measure to explore questions pertaining to accruals characteristics (i.e. Francis et al., 2004, 2005; Dechow et al., 2010). ${ }^{5}$

In summary, the negative association between contemporaneous accruals and cash flows is well established in the literature. However, there is some sporadic evidence in studies using a more recent sample period suggesting that the association between accruals and cash flows has become less pronounced in recent years. For example, Barone and Magilke (2009) find a Pearson (Spearman) correlation of -0.04 (-0.33) between levels of operating cash flows and total accruals on the pooled 1988-2004 time period. Givoly and Hayn (2000) find that the covariance between accruals and cash flows increased from about -0.01 in the $1960 \mathrm{~s}-1980$ s to -0.005 in the $1990 \mathrm{~s}$. In this paper, we examine whether the negative association between accruals and cash flows has weakened over time and, if so, explore the potential reasons for such attenuation.

Our paper is closely related to Dichev and Tang (2008) and Srivastava (2014), which both examine a temporal change in the properties of accounting earnings over the past decades. Dichev and Tang (2008) document a persistent decline in matching between revenues and expenses and the effect of this decline on earnings volatility, persistence and reversibility of changes. Conceptually, both the timing role of accruals and the matching of revenues and expenses are key elements of the accrual accounting system and thus are inherently related to each other. Our investigation can be viewed as further development on the theme of accrual accounting evolution from the accruals vs. cash flow perspective. The accrual perspective may

\footnotetext{
${ }^{5}$ There is a debate in the literature about whether the smoothing property of accruals improves or impedes earnings informativeness. In contrast to works noted above, some have adopted the view of smoothing as an earning management mechanism (i.e. Beatty et al., 2002; Leuz et al., 2003). For example, Myers et al. (2007) document a stronger negative correlation between changes in quarterly cash flows and accruals for firms with strings of consecutive EPS increases (although for both control and 'suspect' groups the correlation is below -0.9 in the pooled 1963-2004 period). Dechow and Skinner (2000) discuss the difficulty of distinguishing between quality-enhancing smoothing and 'abusive' earnings management and suggest the existence of an inversion point in managers' accrual decision. In light of this inherent difficulty, we do not address the question of whether the attenuation in the negative contemporaneous association reflects a change in earnings quality or earnings management or both.
} 
differ from revenue/expense perspective. In a given period, some transactions may affect the timing of accruals and cash flows but not the matching between revenues and expenses. For example, suppose a firm receives cash from a customer in advance of the delivery of the goods or services. All else equal, this transaction leads to higher cash flows and lower accruals in period $t$, but it does not affect any expenses recognized in period $t$ with the matching principle. On the other hand, other transactions may affect the matching between revenues and expenses but not the timing of accruals and cash flows. For example, the imposed requirement to expense employee stock options should increase the matching of expenses to the appropriate revenue, but it should not change the smoothing property of accruals. Therefore, one may envision an accounting reporting evolution where the matching of revenues and expenses is increasingly disrupted over time, while the timing role of accruals, whether intended or nefarious, remains unchanged and vice versa. ${ }^{6}$ However, both this study and Dichev and Tang (2008) support the view that the prominence of matching as the fundamental principle in the determination of earnings has significantly deteriorated over time.

Srivastava (2014) examines whether shifts in the real economy, and specifically the growth in prominence of firms with high intangible intensity, explain the bulk of the temporal changes in earnings properties. He finds that such sample composition changes are significantly responsible for the decrease in the relevance of earnings and the matching between revenues and expenses documented respectively by Collins et al. (1997) and Dichev and Tang (2008). The growth in intangible-intensive firms could be related to our documented attenuation of the association between contemporaneous accruals and cash flows. The operating cash outflows

\footnotetext{
${ }^{6}$ Empirically, we find that the disappearing correlation between accruals and cash flows is not explained by the decline in the matching between revenues and expenses. In terms of magnitude, the decline is much more dramatic for the overall correlation between accruals and cash flows (a drop from about $70 \%$ to $10 \%$ ) than for Dichev and Tang's matching between revenues and expenses (a drop from 99\% to 94\%) in our 1964-2014 sample period.
} 
related to the development of intangible assets such as patents, trade names, human capital, and customer relations are typically immediately expensed and do not generate contemporaneous accruals. However, it is also possible that our observed attenuation is supplementary or unrelated to sample composition changes documented by Srivastava. As discussed above, the accrual accounting changes may be independent of the matching decline, and the increases in nontiming-related accrual recognition could be evident for both "old" and "new" economy firms.

\section{Sample and Definition of Variables}

We obtain our sample data from Compustat and limit the sample to firm-years with nonmissing accruals, cash flows, and average total assets variables. We use the balance sheet approach to estimate total accruals before 1988 because firms were not required to disclose the statement of cash flows until the promulgation of SFAS No. 95 in 1987. Specifically, before 1988, total accruals $(T A C C)$ are defined as changes in non-cash current assets less changes in non-debt current liabilities minus depreciation expense, scaled by average total assets. Cash flows $(C F O)$ are cash flows from operations measured as earnings minus total accruals, where earnings $(E)$ are earnings before extraordinary items scaled by average total assets. To address the fact that the balance sheet-based accruals suffer from measurement errors, especially for firms with merger and acquisition activity or discontinued operations (Hribar and Collins, 2002), we estimate the total accruals from the statement of cash flows from 1988 onwards. ${ }^{7}$ Thus, post 1987, cash flows (CFO) are cash flows from operations as disclosed on the statement of cash flows, scaled by average total assets. Total Accruals (TACC) are measured as earnings scaled by average total assets minus cash flows, where earnings are from the statement of cash flows. Following the prior literature we exclude financial firms (SIC two digit code from 60 through

\footnotetext{
${ }^{7}$ Our results are robust to estimating the total accruals with the balance sheet approach for the full sample.
} 
69) and firm-years with significant acquisition activity (ratio of sales from mergers and acquisitions to net sales over five percent). ${ }^{8}$ Our final sample consists of 217,164 firm-year observations from 1964 to 2014 (inclusive). While we use total accruals in the main analysis on the premise that total accruals best capture the difference between accrual accounting and cash accounting, the empirical results are basically identical if we use working capital accruals (untabulated).

Table 1 presents the descriptive statistics and the correlation matrix of the variables of interest. The descriptive statistics are generally in line with existing research (such as Table 2 of Dechow and Dichev, 2002). The mean total accruals and operating cash flows are -0.054 and 0.050 , respectively. ${ }^{9}$ The Pearson (Spearman) correlation between total accruals and contemporaneous cash flows from operations on the pooled basis is expectedly negative at -0.14 (-0.39). In line with the timing role of accruals, the Pearson correlations between both total accruals and past and future cash flows from operations are positive and statistically significant. Similar to Dechow and Dichev's (2002) results, we find that the positive Pearson correlations between accruals and past/future cash flows are smaller in magnitude than the negative correlation between accruals and contemporaneous cash flows. The Spearman correlation between total accruals and past and future cash flows from operations is small and negative. As discussed in Dechow and Dichev (2002) we may observe this within simple correlations because the positive autocorrelation in cash flows combined with the negative correlation between accruals and contemporaneous cash flows counteract the expected positive relation.

\section{Results}

\footnotetext{
${ }^{8}$ Our results are robust to the inclusion of financial firms and/or inclusion of firm-years with significant M\&A activity.

${ }^{9}$ The mean total accruals are negative because of the depreciation expense.
} 


\subsection{Main results}

\subsubsection{Dechow (1994) model}

We begin our analysis with the exploration between contemporaneous accruals and cash flows over time. Dechow (1994) shows that accruals and cash flows are negatively correlated because accruals tend to mitigate timing and matching problems in cash flows when reflecting firm performance. We capture this relation by regressing total accruals on cash flows from operations, as shown in equation (1a). We run equation (1a) each year and examine $\beta_{1}$, the coefficient on $C F O$, and the adjusted $\mathrm{R}^{2}$, a measure of the model's goodness of fit, over time.

$$
T A C C_{t}=\beta_{0}+\beta_{1} C F O_{t}+e_{t}
$$

where $T A C C$ and $C F O$ are total accruals and cash flows from operations, respectively. ${ }^{10}$

We present the results of the annual regressions in Panel A of Table 2 . The adjusted $\mathrm{R}^{2}$ from equation (1a) has dropped from about $70 \%$ in 1960 s to near zero in more recent years, suggesting that the relative prominence of the timing role of accrual accounting has dramatically declined over time. In a similar vein, the coefficient $\beta_{1}$ has increased from about -0.7 to -0.02 over the past fifty years. To perceive the economic magnitude, the results can be interpreted as follows: a negative cash flow shock of $\$ 1$ is, on average, associated with a 70 cents increase in accruals in the 1960 s but only a 2 cents increase in recent years. Note that the $\mathrm{R}^{2}$ cannot drop below zero, which limits the downside for the adjusted $\mathrm{R}^{2}$.

For completeness, we note that prior research and theory has frequently focused on the relation between the changes, rather than the levels, in accruals and cash flows (McNichols and Wilson, 1988; Leuz et al., 2003). To address this alternative specification we estimate equation (1b) in a similar fashion.

\footnotetext{
${ }^{10}$ We include the subscript $t$ even in models run in the cross-section each year for stylized consistency with the Dechow and Dichev model which requires subscripts to denote the past, present and future cash flows.
} 


$$
\Delta \operatorname{TACC}_{t}=\beta_{0}+\beta_{1} \Delta C F O_{t}+e_{t}
$$

where $\triangle T A C C$ and $\triangle C F O$ are annual changes in total accruals and cash flows from operations, respectively.

The results of the annual changes regressions are presented in Panel B of Table 2 and are qualitatively similar to the levels results. The adjusted $\mathrm{R}^{2}$ from equation (1b) has dropped from about $90 \%$ in 1960 s to under $10 \%$ at its lowest in 2000 and has remained at approximately $15 \%$ hereafter. The coefficient $\beta_{1}$ has increased from about -0.9 to -0.4 from 1960 s to 2000 and has remained above -0.6 subsequently.

In Panels $\mathrm{C}$ and $\mathrm{D}$ of Table 2, we examine the changes in the adjusted $\mathrm{R}^{2}$ and the coefficient $\beta_{1}$ from models (1a) and (1b) respectively in a more systematic fashion by regressing each on a time trend. In both panels, t-statistics in parentheses are adjusted for Newey-West autocorrelations of three lags. We observe that the coefficient on the time trend is negative (positive) and statistically significant for the adjusted $\mathrm{R}^{2}\left(\beta_{1}\right)$ and the goodness of fit of the model is over $85 \%$ for both levels and changes specifications. The fitted values for the beginning and ending year of the sample confirm the drastic decline in the smoothing relationship. Figure 1 presents the results from Table 2 in graphical form. It highlights the continuity and smoothness of the decline (increase) of the adjusted $R^{2}\left(\beta_{1}\right)$ over time, suggesting that the pattern is not attributable to a regime shift.

\subsubsection{Dechow and Dichev (2002) model}

Next, we consider the Dechow and Dichev (2002) model that regresses total accruals on past, current, and future cash flows, as shown in equation (2).

$$
\text { TACC }_{t}=\beta_{0}+\beta_{1} C F O_{t-1}+\beta_{2} C F O_{t}+\beta_{3} C F O_{t+1}+e_{t}
$$


We show the results of the annual regressions in Panel A of Table 3 . The adjusted $\mathrm{R}^{2}$ from equation (2) has dropped from about $70 \%$ in the 1960 s to below $10 \%$ in the latest years, and $\beta_{2}$, the coefficient on contemporaneous cash flows, has increased from about -0.8 to -0.4 over the same time period. In Panel B of Table 3 , we regress the adjusted $\mathrm{R}^{2}$ and cash flow coefficients from model (2) on a time trend. The coefficient on the time trend is negative (positive) and statistically significant for the adjusted $\mathrm{R}^{2}\left(\beta_{2}\right)$ and the goodness of fit of the model is approximately $90 \%$ for both. The fitted values at the beginning and ending sample period years exhibit an even more pronounced change than that observed in the results from the annual regressions.

We do not offer a directional prediction regarding the change in the association between accruals and past and future cash flows. One possibility is that the attenuation of the contemporaneous association is partnered with a decline in the positive association with adjacent cash flows for the same reason that affects the overall correlation between accruals and cash flows when accruals are increasingly not utilized to smooth temporal variations in cash flows. An alternative possibility is that the loss of the negative association between accruals and contemporaneous cash flows is coupled with an increase in the association between accruals and adjacent cash flows. This change could happen if the past/future cash flows related to current accruals comprise a greater portion of the total cash flows while the portion of the current cash flows related to current accruals decreases (i.e. the error component in past and future cash flows decreases while the error component in the current cash flows increases). Turning to the observed coefficients on past and future cash flows in Panel A of Table 3, we find that the timeseries changes are relatively small in magnitude. The coefficient on past cash flows, denoted as $\beta_{1}$ in model (2), has increased from an average of 0.16 in the first tend to an average of 0.21 in 
the last ten years of the sample. A time trend regression in Panel B shows that the increase is statistically significant but of a much smaller magnitude than an increase for the contemporaneous cash flow coefficient. The coefficient on future cash flows, denoted as $\beta_{3}$ in model (2), has increased from about 0.04 in the early to about 0.20 in the latest years of the sample. The coefficient on the time trend in Panel B is about half the magnitude on the coefficient on the time trend for contemporaneous cash flows. These relatively small temporal changes in the coefficients on adjacent cash flows suggest that the dramatic decline in the adjusted $\mathrm{R}^{2}$, a measure of greatest interest to us, is driven mainly by the loss of the association between contemporaneous accruals and cash flows. This is consistent with the notion that while the conceptual timing role of accrual accounting has remained unchanged, its relative prominence has drastically declined.

Figure 2 presents the results from Table 3 in graphical form. Panel A shows a relatively smooth and persistent decline of the adjusted $\mathrm{R}^{2}$, a summary measure of the mapping between accruals and cash flows. Panel B shows the temporal variation in the coefficients on the past, current, and future cash flows in the Dechow and Dichev (2002) model. As discussed previously, we observe a pronounced attenuation of the negative coefficient on contemporaneous cash flows and small increases of the coefficients on past and future cash flows.

Overall, the results in Section 4.1 indicate that the negative association between contemporaneous accruals and cash flows has dramatically shrunk over the past fifty years. This is evidenced by a striking temporal decrease in the adjusted $\mathrm{R}^{2}$ and the temporal increase in the coefficient on contemporaneous cash flows in the accruals models based on Dechow (1994) and Dechow and Dichev (2002). Furthermore, the attenuation of the overall correlation between accruals and cash flows over the years occurred in a smooth and gradual fashion. 


\subsection{Possible explanations}

Having documented the drastic decline in the magnitude of the overall correlation between accruals and cash flows, we now explore the potential reasons for the observed attenuation.

\subsubsection{Economic-based and. timing-related cash flow shocks}

Cash flows may fluctuate as a result of either economic-based or timing-related events. Economic-based cash flow shocks represent fundamental shocks in firm performance and are reflected in reported earnings independent of contemporaneous accruals. In contrast, timingrelated cash flow shocks stem from the inter-temporal variability of cash flows and thus are negatively correlated with accruals. In this section, we consider a possibility that the relative importance of economic-based and timing-related cash flow shocks may have changed over time.

Dechow and Dichev (2002) note that the ability of accruals to map into cash flows is, in theory, related to cash flow volatility. An increase in cash flow volatility over the sample period could lead to a disruption in the expected stable relationship between cash flows and accruals stipulated by the timing role of accrual accounting. Mathematically, the $\mathrm{R}^{2}$ and the cash flow coefficient in equation (1a) can be written as $\frac{\operatorname{COV}^{2}(A C C, C F O)}{V A R(A C C) * V A R(C F O)}$ and $\frac{\operatorname{COV}(A C C, C F O)}{V A R(C F O)}$, respectively. Thus, cash flow volatility $(V A R(C F O))$ directly affects both the $\mathrm{R}^{2}$ measure and the cash flow coefficient. Cash flow variability has both economic-based and timing-related components. We disentangle the two by using the lag-one autocorrelation in cash flows changes to proxy for timing-related cash flow shocks. Timing-related cash flow shocks tend to reverse in subsequent periods, suggesting a negative autocorrelation in changes in cash flows. Intuitively, this negative autocorrelation indicates timing noise in cash flows, and "good" accruals absorb this noise, 
mitigating its effect on earnings. Less noise in cash flows over time may call for a diminished smoothing role of accruals, suggesting a negative link between the timing role of accruals and the autocorrelation in cash flows changes. To address the second source of cash flow variability, we proxy for economic-based cash flow shocks with a measure of the cash flow volatility after controlling for the lag-one autocorrelation in changes in cash flows. In untabulated analysis we observe that the lag-one autocorrelation in changes in cash flows is consistently negative throughout our sample, indicating continuous presence of timing-related cash flow shocks. It is largely flat from 1960s to mid 1990s and exhibits a slight increase in the last twenty years of the sample (from approximately -0.4 to -0.3 ). The last twenty years of the sample also exhibit a growing gap in the standard deviations of total accruals and cash flows from operations. Both metrics are at roughly 0.11 in the early 1990 s and diverge to about 0.14 and 0.19 for accruals and cash flows respectively in the latest years of the sample. Together, the increasing gap in volatilities and the relatively small change in autocorrelation of cash flow changes, suggest relative growth (decline) in economic-based (timing based) cash flow shocks in the last twenty years of the sample.

To examine whether a temporal increase in the operating cash flow volatility or a decline in the magnitude of the autocorrelation in changes in cash flows are responsible in part or in full for the attenuation of the accrual-cash flow link, we run the time-series regression (3a) on the sample period.

$$
\operatorname{Adj} . R^{2}(D D)_{t}=\beta_{0}+\beta_{1} \text { Time }+\beta_{2} \operatorname{Std}(C F O)_{t}+\beta_{3} \text { Auto_ } \Delta C F O_{t}+e_{t}
$$

where the dependent variable is adjusted $\mathrm{R}^{2}$ from the Dechow and Dichev (2002) regression as represented in model (2). This variable captures the goodness of fit of the model where accruals are determined solely by the past, present, and future operating cash flows and thus is a good 
proxy for the overall correlation between accruals and cash flows. Time is a time trend represented as the number of years from 1964. Std(CFO) is the cross-sectional standard deviation of cash flows from operations calculated annually. Auto_ $\triangle C F O$ is the average lag-one autocorrelation in changes in cash flows from operations calculated annually.

We present the results of the regression model (3a) in Table 4. Column 2 indicates that the coefficient on $\operatorname{Std}(C F O)$ is negative and statistically insignificant and the coefficient on Auto_ $\triangle C F O$ is negative and marginally significant suggesting that a decrease in the frequency or the magnitude of timing-related cash flow shocks may contribute to the declining timing role of accruals over time. ${ }^{11}$ Notably, cash flow effects do not subsume the effect of the time trend. While the latter declines from -0.016 in column 1 to -0.014 in column 2 , it remains statistically significant. Overall, the results included in this section suggest that the growth in economicbased cash flow shocks did not significantly contribute to the decline in the association between accruals and cash flows, while a relative decline in the timing based shocks may have played a limited role.

\subsubsection{Timing-related vs. non-timing-related accruals}

Conceptually, accruals include two components: timing-related and non-timing-related. Timing-related accruals offset temporary fluctuations in cash flows whereas non-timing-related accruals stem from conservatism, mark-to-market accounting, accrual estimation errors, earnings management, and other events and estimates that are not directly related to contemporaneous or adjacent time period cash flows. While timing-related accruals are negatively correlated with operating cash flows, non-timing-related accruals are not. An increase in the frequency or

\footnotetext{
${ }^{11}$ Recall that a negative autocorrelation in changes in cash flows is inherent to the timing role of accruals. If the autocorrelation increases (becomes less negative), as it did in our sample, then there are less timing-related shocks to operating cash flows. Accruals may then be utilized less to smooth the noise in cash flows and the degree to which cash flows explain accruals will decrease. Thus, if the timing role of accruals decreases because of shrinkage in the negative autocorrelation of cash flows, one would expect the coefficient to be negative.
} 
magnitude of non-timing-related accruals is thus expected to shrink the overall correlation between accruals and cash flows.

We first use one-time items and non-operating items to proxy for non-timing-related accruals. Prior literature shows that non-recurring items have drastically increased over time (Bradshaw and Sloan, 2002). Because one-time items are by definition (or at least should be) transient and do not play into the accrual accounting smoothing of earnings, they may be contributing to the observed attenuation of the correlation between accruals and cash flows. Although our main analysis already excludes extraordinary items from the measure of earnings, we extend our work by considering the effect of special items and non-operating items, which have drastically increased in both frequency and magnitude over the past fifty years.

Next, we consider the implications of loss firms for the association between accruals and cash flows. The frequency of firms reporting losses has increased dramatically over the years (Hayn, 1995; Klein and Marquardt, 2006), a fact that may contribute to the attenuation of the correlation between accruals and cash flows. ${ }^{12}$ Arguably, many losses are not directly related to operating cash flows and thus serve as a good proxy for non-timing-related accruals. However, the frequency of firm-year losses may overlap with the first proxy considered above, as negative one-time items may shift the reported earnings into loss territory. In addition, the frequency of firm-year losses could also capture economic-based cash flow volatility, addressed in the prior section, as firms subject to greater economic shocks are more likely to report losses. In that

\footnotetext{
${ }^{12}$ The frequency of losses increases from about 3\% in 1960 s to over $30 \%$ in more recent years in our sample. When we estimate the adjusted $\mathrm{R}^{2}$ from the Dechow and Dichev model separately for profit and loss subsamples, we find that the Dechow and Dichev adjusted $\mathrm{R}^{2}$ declines for both profit and loss firms, but the decline is more dramatic for loss firms: from $78 \%(68 \%)$ in the 1960 s to about $50 \%(15 \%)$ in the most recent decade for profit (loss) firms. A decline in the adjusted $\mathrm{R}^{2}$ for both subsamples suggests that the information content of accruals has changed over time for both profit and loss firms. A sharp drop in the adjusted $\mathrm{R}^{2}$ over time for loss firms is consistent with the idea that losses in the later years are more likely to be attributable to one-time items and economic fluctuations unrelated to contemporaneous cash flows as compared to losses in the earlier periods. This effect, coupled with a high frequency of losses in more recent years, reduces the correlation between accruals and cash flows for the overall sample.
} 
sense, the frequency of firm-year losses is a proxy for both non-timing-related accruals and economic-based cash flow shocks.

We test the effect of one-time items, non-operating income, and reported losses by running the time-series regression ( $3 b)$ on our sample.

$$
\text { Adj. } R^{2}(D D)_{t}=\beta_{0}+\beta_{1} \text { Time }+\beta_{2} \operatorname{Std}(\mathrm{OI}-\mathrm{PTI})_{t}+\beta_{3} \text { PctLoss }_{t}+e_{t}
$$

where the dependent variable and Time are defined as in model (3a). PctLoss is the annual frequency of firms with earnings before extraordinary items less than zero. Std(OI-PTI) is the cross-sectional standard deviation of the difference between operating income after depreciation and pre-tax income. The difference OI-PTI largely captures special items such as impairments, restructuring charges, and gains and losses from extinguishment of debt, but it also includes nonoperating income/expense, such as realized or unrealized gains or losses from investments. Untabulated results indicate that the magnitudes and volatilities of both of these categories have increased drastically over the time period examined. Furthermore, the presence and extent of these items may be correlated with other one-time items aggregated with recurring income in the reporting process and thus not explicitly identified as "special items." Conceptually, because most of these non-recurring items do not have operating cash flow impacts in contemporaneous or adjacent time periods, their presence is expected to reduce the magnitude of the correlation between accruals and cash flows.

Column 3 in Table 4 contains the regression results from model (3b). We find that the coefficient on $\operatorname{Std}(O I-P T I)$ is insignificantly negative and that the coefficient on PctLoss is negative and statistically significant. The inclusion of Std(OI-PTI) and PctLoss reduces the coefficient on Time to -0.006 (from -0.016 in column 1). In untabulated analysis, we in turn include $S t d(O I-P T I)$ or PctLoss as an explanatory variable in the regression of the adjusted $\mathrm{R}^{2}$ on 
Time and find that when considered separately both coefficients are highly negative and statistically significant. ${ }^{13}$ Overall, the results suggest that the increase in the frequency and magnitude of non-timing-related accruals contributes to the attenuation in the overall correlation between accruals and cash flows.

\subsubsection{Poor matching between revenues and expenses}

Next, we consider the effect of the temporal change in the matching between revenues and expenses. The FASB's slow push of balance sheet accounting towards greater prominence may have changed the role of accruals over time (Dichev, 2008). Among the standards which denote the ascent of fair value accounting are those on the determination and treatment of goodwill, reporting for financial assets, and impairments of fixed assets. Dichev and Tang (2008) document the aggregate effects of the regulatory evolution in the context of the loss of matching between recognized revenues and expenses. They find a continuous and pronounced decline in the contemporaneous correlation between revenues and expenses and corresponding changes in earnings properties such as increased volatility, decreased persistence, and greater negative autocorrelation. Conceptually, the poor matching between revenues and expenses is related to non-timing-related accruals discussed earlier.

To examine whether a temporal decrease in the matching of revenues and expenses documented by Dichev and Tang (2008) is related to the attenuation of the overall correlation between accruals and cash flows, we run equation (3c) on the sample period.

$$
\operatorname{Adj} . R^{2}(D D)_{t}=\beta_{0}+\beta_{1} \text { Time }+\beta_{2} \operatorname{Adj} . R^{2}(D T)_{t}+e_{t}
$$

where the dependent variable and Time are defined as in model (3a). $A d j . R^{2}(D T)$ is the adjusted

\footnotetext{
${ }^{13}$ As noted above, because there is non-trivial overlap between instances of firm-year losses and negative one-time and non-operating items it is not surprising that the significance of the latter is subsumed in the multivariate model. We address the multicollinearity issue further below.
} 
$\mathrm{R}^{2}$ from the Dichev and Tang (2008) model run annually, which serves as a proxy for the matching between revenues and expenses ${ }^{14}$ :

$$
\operatorname{SALE}_{t}=\beta_{0}+\beta_{1} \text { EXPENSE }_{t-1}+\beta_{2} \operatorname{EXPENSE}_{t}+\beta_{3} \operatorname{EXPENSE}_{t+1}+e_{t}
$$

where SALE are the net sales scaled by average total assets and EXPENSE are expenses measured as sales minus earnings before extraordinary items scaled by average total assets.

The results of the regression model (3c) are reported in column 4 of Table 4 . We observe a negative and statistically insignificant coefficient on $\operatorname{Adj}^{2} R^{2}(D T)$, suggesting that the decline in matching between revenues and expenses over time observed by Dichev and Tang (2008) did not significantly contribute to the loss of the correlation between accruals and cash flows. The coefficient on Time retains its negative magnitude and statistical significance. This result is corroborated by the (untabulated) observation that while the goodness of fit metrics from the Dechow (1994) and Dechow and Dichev (2002) models declined by over 70 percent, the goodness of fit metric of Dichev and Tang (2008) decayed by only about 15 percent.

\subsubsection{Intangible intensity}

Srivastava (2014) examines whether the temporal decrease in the relevance of earnings and the matching between concurrent revenues and expenses documented respectively by Collins et al. (1997) and Dichev and Tang (2008) is driven by changes in the real economy or changes in the accounting standards. He finds that the observed patterns are, for the most part, due to changes in the composition of firms in the US economy, and particularly the growing prominence of firms with high intangible intensity. The same factors that contribute to the negative relationship between intangible intensity and average earnings quality measures could be applicable to explaining the attenuation of the accrual-cash flow relation. Namely the growing

\footnotetext{
${ }^{14}$ The results are qualitatively similar if we use the coefficient on EXPENSE $_{\mathrm{t}}$ as the proxy for the matching between revenues and expenses.
} 
investments in intangible assets such as patents, trade names, human capital, and customer relations all represent transactions which are, for the most part, expensed upon the outflow of cash and, thus, do not lead to the contemporaneous generation of accruals. To examine whether a temporal increase in the intangible intensity is responsible in part or in full for the attenuation of the accrual-cash flow link, we run the time-series regression (3d) on the sample period.

$$
\operatorname{Adj} . R^{2}(D D)_{t}=\beta_{0}+\beta_{1} \text { Time }+\beta_{2} S G \& A_{-} \text {Intensity } t+e_{t}
$$

where the dependent variable and Time are defined as in model (3a). SG\&A_Intensity is annual average of the selling, general, and administrative expenses scaled by total expenses, the latter equal to sales minus earnings before extraordinary items. Column 5 in Table 4 contains the regression results from model (3d). We find that the coefficient on $S G \& A_{-}$Intensity is insignificantly negative. The decline in the magnitude of the negative coefficient on the time trend variable from column 1 to column 5 reveals that when considered alone, about $25 \%$ $[=(0.016-0.012) / 0.016]$ of the timing role decline is related to the temporal growth in intangible intensity documented by Srivastava (2014). ${ }^{15}$

Our main model in column 6 of Table 4 includes all six of the potential explanatory variables for the attenuation of the correlation between accruals and cash flows. We find that in this specification the coefficient on Time increases to $-0.006(\mathrm{t}=-2.02)$. The coefficients on Std(OI-PTI) and PctLoss are significantly negative, confirming our expectation that one-time and non-operating items and the frequency of losses contribute to the attenuation in the correlation between accruals and cash flows. The coefficients on cash flow volatility and autocorrelation are insignificant while retaining an expected sign. The coefficient on $S G \& A_{-}$Intensity remains negative and insignificant. ${ }^{16}$ Lastly, the coefficient on adj. $R^{2}$ (Dichev-Tang) becomes negative

\footnotetext{
${ }^{15}$ We further explore the role of sample composition changes identified by Srivastava (2014) in section 5.2.

${ }^{16}$ Both cash flow autocorrelation and SG\&A Intensity are marginally significant in one-tailed tests.
} 
and significant, suggesting that it captures measurement errors in the other explanatory variables as the expected sign is positive.

One caveat in identifying potential explanations for the attenuation in the correlation between accruals and cash flows is that the explanatory variables considered in Table 4 are highly correlated. The magnitude of Pearson correlations between the six explanatory variables ranges from 0.5 to 0.9 , while the time series examined provide only 51 observations for each variable. Multicollinearity could increase the standard error and thus render the coefficient estimate on one or more variables to be statistically insignificant. The second caveat is that any variable that is mechanically related to the time trend, such as the authors' age over time, is likely to exhibit significant coefficients. In light of these two caveats, we adopt the following criteria when interpreting the results. First, each explanatory variable should have a strong economic theory or intuition. Second, the explanatory variable should have a significant coefficient with the expected sign in the stand-alone regression, and the coefficient must not flip its sign from the stand-alone regression to the full model presented in column 6 . Under these criteria, we interpret the results in Table 4 to mean that one-time and non-operating items, and loss firms are mostly responsible for the attenuation in the overall correlation between accruals and cash flows and explain the majority of the effect (about $63 \%=(0.016-0.006) / 0.016)$. The temporal changes in economic and timing based cash flows shocks and in intangible intensity are all related to the observed attenuation of the accruals-cash flow link, but that effect is subsumed by other explanatory variables.

\subsubsection{Asymmetrically timely recognition of gains and losses}

As Ball and Shivakumar (2006) point out, another inherent property of accrual accounting is asymmetrically timely recognition of gains and losses. Because revisions in the 
current period cash flows from a durable asset are likely to be positively correlated with revisions in its expected future cash flows, the timely gain and loss recognition role of accruals suggests a positive correlation between accruals and contemporaneous cash flows. This positive correlation will tend to offset the negative correlation from the timing role of accrual accounting in a linear specification, such as equation (1a). Because losses are generally recognized in a more timely fashion than gains, the positive correlation will not be symmetric. It is possible that the effect of the asymmetrically timely gain and loss recognition gets stronger over the observed period and thus attenuates the negative coefficient on cash flows from equation (1a) in the recent years.

To incorporate the asymmetrically timely recognition of economic gains and losses via accruals into our analysis, we follow Ball and Shivakumar's (2006) extension of the cash flow model and estimate equation (4) over the sample period. ${ }^{17}$

$$
\text { TACC }_{t}=\beta_{0}+\beta_{1} C F O_{t}+\beta_{2} D+\beta_{3} D * C F O_{t}+e_{t}
$$

where $D$ is equal to one if annual $\triangle C F O_{t}$ is negative and zero otherwise. We also consider an alternative specification of $D$ which is equal to one if $C F O_{t}$ is negative and zero otherwise. If the observed decline in the correlation between accruals and cash flows, as evidenced by the unadjusted Dechow (1994) model results reported in Table 2, is in large part due to the change in the asymmetrically timely gain and loss recognition, then the adjusted $\mathrm{R}^{2}$ from equation (4) should not change significantly over time.

The results of the adjusted $\mathrm{R}^{2}$ from the annual regressions are plotted in Panels A and $\mathrm{C}$ of Figure 3 and show a continuous and smooth decline for both specifications of $D$. The key finding is that for both specifications the adjusted $\mathrm{R}^{2}$ from equation (4) has dropped from about $70 \%$ in the 1960 s to under $10 \%$ in the more recent years, a decline very comparable to that in the

\footnotetext{
${ }^{17}$ The results are largely unchanged if we drop D from equation (4).
} 
unadjusted Dechow (1994) model reported in Panel A of Table 2. In Panel B we observe that the coefficient on $D^{*} C F O_{t}$, where $\mathrm{D}$ equals 1 when $C F O_{t}$ is negative, is significantly negative in the first ten years of the sample, suggesting that for this period the interaction variable does not capture well the economic loss recognition role under this specification. The coefficient, on average, is positive and increasing from mid 1970s to 2000, in line with Ball and Shivakumar's (2006) conjecture that the conservative recognition of expected losses has increased over that time period. It declines slightly afterwards. When considering the specification where D equals 1 when $\triangle C F O_{t}$ is negative in Panel $\mathrm{D}$, we observe that the coefficient on $D^{*} C F O_{t}$, is largely zero in the first fifteen years of the sample, suggesting a limited loss recognition role of accruals during that period. The coefficient oscillates between zero and 0.25 in the remaining years but no pronounced increase is evident. Using the levels (changes) specification of $C F O_{t}$ to define $D$, the coefficient on $C F O_{t}$ increases from $-0.67(-0.65)$ in 1980 , when the loss recognition coefficient consistently takes on the expected sign, to about $-0.35(0.00)$ in the recent years, indicating a declining timing role of accruals over this thirty year period. In untabulated analysis we regress both coefficients and the goodness of fit metric from the Ball and Shivakumar (2006) model on a time trend and observe expected, statistically significant, relationships.

Overall, we conclude that the attenuation in the correlation between accruals and cash flows is not significantly driven by an offsetting increase in the accruals' role of timely gain and loss recognition. The adjusted $\mathrm{R}^{2}$ from Ball and Shivakumar (2006) non-linear specification declines over time in a similar manner to the one from Dechow (1994) linear specification.

\section{Robustness and Implications}

\subsection{Firm-specific time-series regressions}


We conduct cross-sectional regressions in the main analysis presented above in line with most accrual accounting literature. In this section, we examine the relationship between accruals and cash flows using firm-specific time-series regressions. Specifically, we break our sample period into four subperiods: 1964-1975, 1976-1987, 1988-1999, 2000-2014. Then in each subperiod, we estimate equations (1a) and (2) by firm. Panels A and B of Table 5 report summary statistics of the coefficient estimate on $C F O$ and the adjusted $\mathrm{R}^{2}$ from the Dechow (1994) and the Dechow and Dichev (2002) models respectively. We find that the correlation between accruals and cash flows considerably decayed over time even in these firm-specific time-series regressions. In Panel A, the median $C F O$ coefficient estimates from equation (1a) increased from -0.91 in 1964-1975 to -0.82 in 1976-1987, further to -0.65 in 1988-1999, and finally to -0.43 in 2000-2014. The median adjusted $\mathrm{R}^{2}$ declined from 0.84 in 1964-1975 to 0.71 in 1976-1987, further to 0.37 in $1988-1999$, and finally to 0.16 in $2000-2014$. The results from equation (2) exhibit a similar, albeit slightly weaker, pattern in Panel B. In sum, the results from firm-specific time-series regressions corroborate those from cross-sectional regressions in the main analysis, suggesting that our results are not sensitive to regression specifications.

\subsection{Sample composition}

Next, we consider the effects of a change in the sample composition. Because we examine a very long time-series it is feasible that the sample had changed significantly over time, both in terms of specific firms and in terms of distinct industries gaining and losing prominence. Srivastava (2014) documents that the observed changes in various earnings characteristics documented in prior research are, for the most part, driven by the integration of successive cohorts of newly listed firms into the sample. He observes that successive cohorts exhibit progressively higher revenue and cash flow volatility and lower matching between revenues and 
expenses due to their increasing intangible intensity. The growth of firms with considerable investments in intangible assets which are, for the most part, expensed upon cash outflows and do not generate contemporaneous accruals, could contribute to the observed temporal attenuation of the accrual-cash flow relation. Furthermore, newly listed firms are likely to possess some of the characteristics which we find contributory to the attenuation, such as the probability of lossyears. To examine the effect of the sample composition changes we follow Srivastava (2014) methodology of separating the sample into successive listing cohorts by the first year in which a firm's data are available in Compustat. All of the firms with a listing year before 1970 are classified as "pre-1970", while the remaining firms listed in a common decade are referred to as a cohort of firms newly-listed in the 1970s, 1980s, 1990s, and 2000s.

Table 6 presents the number of firm-year observations from the successive listing cohorts in each year and the adjusted $\mathrm{R}^{2}$ of the annual regression of the levels model based on Dechow (1994) for each cohort. ${ }^{18}$ The breakdown of the total sample by listing cohorts closely mirrors that reported in Table 1 of Srivastava (2014). We graphically illustrate the main finding in Figure 4. Two patterns are noteworthy. First, the adjusted $\mathrm{R}^{2}$ from different cohorts are similar to each other in any given window, especially in the $1960 \mathrm{~s}-1990 \mathrm{~s}$ period when the adjusted $\mathrm{R}^{2}$ drops dramatically. ${ }^{19}$ Second, the adjusted $\mathrm{R}^{2}$ exhibit a pronounced decline over the years for each of the cohorts, suggesting that the attenuation of the accrual-cash flow relationship is prevalent both among "old" and "new" economy firms. For example, the adjusted R2 for the pre-1970 cohort drops from about $70 \%$ in 1960 s to around $10 \%$ in 2000 s. When we focus on the period from 2000 forward, we do find that the last two listing cohorts (1990s and 2000s) have lower adjusted $\mathrm{R}^{2}$ than the first two listing cohorts (pre-1970s and 1970s), but the downward trend exists in all

\footnotetext{
${ }^{18}$ We find the same results when using the Dechow and Dichev (2002) model.

${ }^{19}$ The observed volatility in the metrics in the latter periods is driven by the small sample size of surviving firms.
} 
cohorts (although the last two start from very low points). Overall, Table 6 and Figure 4 provide compelling evidence suggesting that the documented attenuation in the accrual-cash flow relation is not driven by the change in the sample composition, in contrast to the findings of Srivastava (2014) for earnings quality metrics.

We further extend the analysis of sample composition effects in several ways. First, we follow the logic of Dichev and Tang (2008) and repeat our analysis on the sample of largest 1,000 firms in each year as measured by total assets. Model 1 of robustness specifications reported in Table 7 shows that the coefficient on the time trend and the goodness of fit of the Dechow and Dichev (2002) model are only slightly decreased (by about 20\% and 13\% respectively), when compared to those reported in the main analysis. We also carry out our analyses on a relatively constant sample of firms with at least 30 (40) years of non-missing data in our sample. Panels A and B of Figure 5 presents the results of the annual regressions of the levels model based on Dechow (1994). We observe the decline (increase) of the adjusted $\mathrm{R}^{2}$ (coefficient $\beta_{1}$ ) over time very similar to that reported in Figure 1 despite a significant reduction in the number of observations per year. Overall, we confirm that our results are not driven by changes in sample composition.

5.3 Alternative definitions of accruals and cash flows in Richardson et al. (2005)

In this section, we consider alternative definitions of accruals and cash flows in Richardson, Sloan, Soliman, and Tuna (2005). Richardson et al. introduce a comprehensive measure of accruals that includes both current and non-current operating and financial accruals. Following Richardson et al., we define $T A C C_{t}$ as changes in non-cash assets minus changes in liabilities scaled by average total assets. $C F O_{t}$ is defined as changes in cash plus net cash distributions to equity scaled by average total assets, where net cash distributions to equity is 
equal to cash dividends plus stock repurchases less equity issuances. Then we repeat our main analysis by estimating equations (1a), (1b), and (2) each year. The adjusted $\mathrm{R}^{2}$ from these three equations exhibit a declining pattern very similar to that reported in the main analysis (untabulated). Model 2 of Table 7 reports the results of regressing the goodness of fit measure from the Dechow and Dichev (2002) model on the time trend when using the Richardson et al. (2005) definitions of accruals. We observe that the coefficient on the time trend is negative and highly significant, albeit a third smaller in magnitude $(-0.010$ compared to the -0.016 reported in the main analysis). These results indicate that our main message of the declining overall correlation between accruals and cash flows is robust to the broad definition of accruals and cash flows in Richardson et al. (2005) and subsequent studies. To the extent that the broad definition of accruals and cash flows contains more measurement errors with respect to the timing role of accruals, we expect the results to be weaker than those based on traditional accrual measures, a conjecture confirmed in Model 2 of Table 7.

\subsection{Other robustness checks}

There could be a number of other operations-based and regulatory reasons why the correlation between accruals and cash flows has diminished over time. We carry out a battery of additional tests to explore alternative explanations to the observed decline in the negative association between accruals and cash flows. The remainder of Table 7 contains the results of analyses which consider the impact of expanding the conceptual smoothing window and industry composition. We briefly address each of these analyses below.

First, we consider the possibility that while the smoothing of cash flows via accruals has decreased over the adjacent periods, the window of smoothing has expanded - i.e. accruals today are expected to correspond to cash flows in non-adjacent fiscal periods. Thus, we expand the 
Dechow and Dichev (2002) model of mapping the past, present, and future cash flows into accruals to include years -2 to +2 (Model 3 of Table 7) and years -3 to +3 (Model 4 of Table 7). We observe that the negative loading of the time trend variable for adjusted $\mathrm{R}^{2}$ is largely unchanged from that reported in Panel B of Table 3.

Next, we repeat the analysis by each 2-digit SIC industry and calculate the descriptive statistics of the adjusted $R^{2}$ from the Dechow (1994) and the Dechow and Dichev (2002) models across industries. Prior research suggests that various changes in characteristics of financial reporting over time are in large part driven by the growth of technology-based industries (Lev and Zarowin, 1999). The mean, 1st quartile, median, and 3rd quartile of the adjusted $\mathrm{R}^{2}$ all decline substantially over time. For the sake of brevity, we only report the regressions of mean and median adjusted $\mathrm{R}^{2}$ from the Dechow and Dichev (2002) model in Table 7. Models 5 and 6 show that the coefficients on the time trend are highly significant, with t-statistics of about 20 , in both mean and median industry-specific adjusted $\mathrm{R}^{2}$ regressions. These results suggest that our main findings are not driven by a specific industry or a significant change in the composition of firms across industries. We complete this analysis by examining whether the potential explanations for the attenuation in the association between accruals and cash flows hold in various industries. Table 8 presents the results of the full model in Table 4 (column 6) across sectors. We find that the coefficients on Time are negative for all sectors. Among potential explanatory variables, Std(OI-PTI) and PctLoss have statistically significant coefficients with expected signs in 4 and 5 (of the total 7) sectors respectively. These results are similar to those reported in Table 4 for the whole sample and confirm that conclusions drawn above regarding the observed attenuation and its likely causes are not limited to a select set of industries. The coefficients on $S G \& A$ intensity are highly significant with expected signs for technology 
$(\mathrm{SEC}=3)$ and services $(\mathrm{SEC}=7)$ sectors, rendering the coefficients on Time to be insignificant, a result consistent with the notion that intangible intensity plays an important role in these two sectors (Srivastava 2014).

Lastly, we carry out several robustness tests untabulated for brevity. We consider the potential impact of a change in the operating cycles of firms. Dechow and Dichev (2002) suggest that the magnitude of the estimation errors in the accrual generating process is related to the length of the operating cycle. Thus, an increase in the average operating cycle could be associated with a decrease in the accrual-cash flow relation due to larger estimation errors. We examine the average annual operating cycle for our sample and find no pattern of a systematic change over the past fifty years. We also consider the effect of using quarterly rather than annual data and carry out the Dechow (1994) levels regression of total accruals on contemporaneous cash flows from operations separately for the four fiscal quarters. We observe a pattern of dramatic decline (increase) in the adjusted $\mathrm{R}^{2}$ (coefficient $\beta_{1}$ ) similar to that reported in the annual analysis in Figure 1. The fourth quarter exhibits the most pronounced change from 1975 to 2011. This is in line with observed explanatory factors reported in our analyses as frequency and magnitude of special items, particularly negative ones, is higher in the fourth fiscal quarter (Potepa, 2014).

Overall, we find that our results on the loss of the correlation between accruals and cash flows are robust to alternative samples, research designs, and specifications.

\subsection{Implications to research}

The models of the accrual-cash flow relationship are ubiquitous in the accounting research literature. Empirical accounting studies most frequently either pool historical data over the full sample or calculate accrual related metrics with firm-specific regressions over the full 
sample period in examining their research questions. Our findings of a temporal change in the structural relation between accruals and cash flows suggest that residual accruals as measured with the Dechow (1994) or the Dechow and Dichev (2002) model and their various modifications, may be systematically biased for the recent years. Carrying out pooled regressions (either for a full sample, an industry, or a given firm) assigns an average intercept and coefficients in the regression of accruals on cash flows. Because the inherent relation has significantly declined over the years the estimated pooled regression would overestimate the intercept and underestimate the coefficient on contemporaneous cash flows for the recent years. The magnitude and variability of the residuals in such models (a metric often interpreted as a measure of accrual quality) could then be systematically biased up or down depending on the magnitude of the estimated coefficients and the values of cash flows. We illustrate that the residual accruals are, in fact, systematically underestimated in more recent years in Table 9.

We estimate the Dechow (1994) levels model and the Dechow and Dichev (2002) model in three ways: with annual regressions, pooled regression, and firm-specific regressions. Each year we calculated the average and the standard deviation of residual accruals across firms under each of the three specifications. We then calculate in turn the difference between the average values of the residual accruals from the pooled regression and annual regressions, and from the firm-specific regression and annual regressions. We repeat the process for the differences in standard deviations. Finally, we regress the difference in average residuals from the Dechow (1994) pooled (firm-specific) and annual regressions on the time trend and report the results in the first (second) specification of Panel A. We observe that the magnitude of residual accruals from the pooled regression is persistently lower than that from the annual regressions for the recent years, as illustrated in the negative coefficient on Time. The residual accruals from the 
firm-specific regressions are also underestimated with time albeit to a smaller degree. We repeat the time trend regression for differences in standard deviations of residual accruals in specifications three and four and observe that the standard deviations are similarly underestimated with time. Panel B reports the results of regressing the differences in residual accruals and in standard deviations of residual accruals from the Dechow and Dichev (2002) paper. Again, we observe that the pooled and the firm-specific regressions increasingly underestimate the residual accrual magnitude and variance with the passage of time as compared to the annual regressions. The direct implication of this finding is that pooled and firm-specific regressions would suggest that earnings are systematically managed downwards in more recent years as a direct artifact of the attenuated accrual-cash flow relationship. We suggest that accounting researchers exploring accrual characteristic metrics utilize annual regressions, particularly in studies on longer time-periods or those examining temporal shifts.

\section{Conclusions}

The negative association between contemporaneous accruals and cash flows is inherent to the timing role of accrual accounting. Both accounting research and teaching largely take the existence of this negative association as given. Using the models based on Dechow (1994) and Dechow and Dichev (2002) to examine the correlation between accruals and contemporaneous cash flows over the past fifty years, we find evidence of a pronounced and continuous decline in this property of accrual accounting. In fact, the negative association between accruals and operating cash flows has nearly disappeared in the recent years. The continuity and smoothness of the attenuation in the correlation between the two components of earnings suggests that the decline is not due to a specific regulatory or environmental regime shift. 
We explore a variety of potential reasons for the decline in the association between accruals and cash flows, including the change in cash flow volatility, the effect of one-time items and non-operating income, the increase in the frequency of loss firms, the loss of matching between revenues and expenses, the rise of intangible-intensive firms, the change in the asymmetrically timely recognition of gains and losses, and industry effects. We find that an increase in one-time and non-operating items, and loss firms, proxies for non-timing-related accruals, to a large degree explain the decline in the association between accruals and cash flows. ${ }^{20}$ On the other hand, the temporal changes in the matching between revenues and expenses and the growth of intangible-intensive industries play only a limited role in explaining the observed attenuation. Furthermore, the relative decline in the timing role does not appear to be driven by an offsetting increase in the alternative roles of accruals, such as the asymmetrically timely recognition of gains and losses.

While we document strong evidence that the correlation between accruals and cash flows has significantly declined, many questions remain unanswered and thus are open to future research. For example, have earnings become less meaningful than before because of the changing nature of the information content of accruals? Should we teach our students about the sample-wide attenuation of the smoothing property when we teach them about the timing role of accruals at the transaction level? Our evidence could also be potentially linked to a number of phenomena documented in the literature. For example, earnings have become less value-relevant in the past few decades (e.g., Collins et al., 1997; Francis and Schipper, 1999). The magnitude of the accrual anomaly has declined significantly over time (Green et al., 2011). The use of

\footnotetext{
${ }^{20}$ Overall we are able to explain about $63 \%$ of the decline in the correlation between accruals and cash flows. The imperfect nature of empirical proxies tends to understate the explanatory power. Additional factors not explicitly examined, such as a temporal change in managerial skills or earnings management behavior, may also contribute to the decline.
} 
financial covenants measured with balance sheet variables, such as leverage and net worth, has been notably reduced in recent years (Demerjian, 2011). The attenuation of the correlation between accruals and cash flows due to economic shocks and greater prominence of non-timing accruals alters the information content of earnings, and other financial variables, and so could be inherently related to these phenomena. Finally, given our finding on the change in the association between accruals and cash flows and its likely sources, it may be of interest to researchers and practitioners to re-examine whether the overall usefulness of accruals and earnings, as utilized in valuation and contracting settings, has changed over time. 


\section{References:}

Ball, R. and L. Shivakumar. 2006. The role of accruals in asymmetrically timely gain and loss recognition. Journal of Accounting Research 44(2), 207-242.

Barone, G. and M. Magilke. 2009. An examination of the effects of investor sophistication on the pricing of accruals and cash flows. Journal of Accounting, Auditing \& Finance 24(3), 385-414.

Barth, M. E., W. R. Landsman, and M. Lang. 2012. Are IFRS-based and US GAAP-based accounting amounts comparable? Journal of Accounting and Economics 54(1), 68-93.

Beatty, A., B. Ke, and K. Petroni. 2002. Earnings management to avoid earnings declines across publicly and privately held banks. The Accounting Review 77(3), 547-570.

Bradshaw, M. and R. Sloan. 2002. GAAP versus the street: an empirical assessment of two alternative definitions of earnings. Journal of Accounting Research 40(1), 41-66.

Collins, D., E. Maydew, and I. Weiss. 1997. Changes in the value-relevance of earnings and book values over the past forth years. Journal of Accounting and Economics 24, 39-67.

Dechow, P. 1994. Accounting earnings and cash flows as measures of firm performance: The role of accounting accruals. Journal of Accounting and Economics 18(1), 3-42.

Dechow, P. and I. Dichev. 2002. The quality of accruals and earnings: The role of accrual estimation errors. The Accounting Review 77(Supplement), 35-59.

Dechow, P., W. Ge, and C. Schrand. 2010. Understanding earnings quality: A review of the proxies, their determinants and their consequences. Journal of Accounting and Economics 50(2-3), 344-401.

Dechow, P., S. P. Kothari, and R. Watts. 1998. The relation between earnings and cash flows. Journal of Accounting and Economics 25(2), 133-168.

Dechow, P. and D. J. Skinner. 2000. Earnings management: reconciling the views of accounting academics, practitioners, and regulators. Accounting Horizons 14(2), 235-250. 
Demerjian, P. 2011. Accounting standards and debt covenants: Has the "balance sheet approach" led to a decline in the use of balance sheet covenants? Journal of Accounting and Economics 52, 178-202.

Dichev, I. 2008. On the balance sheet-based model of financial reporting. Accounting Horizons 22(4), 453-470.

Dichev, I., J. Graham, C. Harvey, and S. Rajgopal. 2013. Earnings quality: Evidence from the field. Journal of Accounting and Economics, forthcoming.

Dichev, I. and V. Tang. 2008. Matching and the changing properties of accounting earnings over the last 40 years. The Accounting Review 83(6), 1425-1460.

Francis, J., R. LaFond, P. Olsson, and K. Schipper. 2004. Costs of equity and earnings attributes. The Accounting Review 79(4), 967-1010.

Francis, J., R. LaFond, P. Olsson, and K. Schipper. 2005. The market pricing of accruals quality. Journal of Accounting and Economics 39(2), 295-327.

Francis, J. and K. Schipper. 1999. Have financial statements lost their relevance. Journal of Accounting Research 37(2), 319-352.

Givoly, D. and C. Hayn. 2000. The changing time-series properties of earnings, cash flows and accruals: Has financial reporting become more conservative. Journal of Accounting and Economics 29(3), 287-320.

Green, J., J. Hand, and M. Soliman. 2011. Going, Going, Gone? The Apparent Demise of the Accruals Anomaly. Management Science 57(5): 797-816.

Hayn, C. 1995. The information content of losses. Journal of Accounting and Economics 20, 125-153.

Hribar, P. and D. Collins. 2002. Errors in estimating accruals: Implications for empirical research. Journal of Accounting Research 40(1), 105-134.

Hribar, P., T. Kravet, and R. Wilson. 2014. A new measure of accounting quality. Review of Accounting Studies 19(1), 506-538. 
Kieso, D. E., J. J. Weygandt, and T. D. Warfield. 2012. Intermediate Accounting (14th ed.). Hoboken, NJ: John Wiley \& Sons, Inc.

Klein, A. and C. A. Marquardt. 2006. Fundamentals of accounting losses. The Accounting Review 81(1), 179-206

Leuz, C., D. Nanda, and P. Wysocki. 2003. Earnings management and investor protection: An international comparison. Journal of Financial Economics 69(3), 505-527.

Lev, B. and P. Zarowin. 1999. The boundaries of financial reporting and how to extend them. Journal of Accounting Research 37(2), 353-385.

McInnis, J. and D. W. Collins. 2011. The effect of cash flow forecasts on accrual quality and benchmark beating. Journal of Accounting and Economics 51(3), 219-239.

McNichols, M. F. and S. R. Stubben. 2014. The effect of target-firm accounting quality on valuation in acquisitions. Review of Accounting Studies forthcoming.

McNichols, M. and G. P. Wilson. 1988. Evidence of earnings management from the provision for bad debts. Journal of Accounting Research 26(Supplement), 1-31.

Myers, J., L. Myers, and D. Skinner. 2007. Earnings momentum and earnings management. Journal of Accounting, Auditing \& Finance 22(2), 249-284.

Potepa, J. 2014. The treatment of special items in determining CEO cash compensation. Working Paper.

Rayburn, J. 1986. The association of operating cash flow and accruals with security returns. Journal of Accounting Research 24(Supplement), 112-133.

Richardson, S., R. Sloan, M. Soliman, and I. Tuna. 2005. Accrual reliability, earnings persistence and stock prices. Journal of Accounting and Economics 39(3), 437-485.

Sloan, R. 1996. Do stock prices fully reflect information in accruals and cash flows about future earnings? The Accounting Review 71(3), 289-315. 
Srivastava, A. 2014. Why have measures of earnings quality changed over time? Journal of Accounting and Economics 57(2-3), 196-217. 


\section{Appendix - Variable Definitions [Compustat mnemonics]}

BM Ratio of the book value of equity [CEQ] to market value of equity [CSHO*PRCC_F] at fiscal year-end

CFO Cash flows from operations calculated as $E-T A C C$ from the beginning of the sample through 1987 and taken as reported on the Statement of Cash Flows $[\mathrm{OANCF}]$ and scaled by average total assets $[\mathrm{AT}]$ from 1988 on

CFO_RSST Cash flows from operations from Richardson, Sloan, Soliman, and Tuna (2005) calculated as changes in cash [CHE] plus cash dividends [DVT] plus stock repurchases [PRSTKC] less equity issuances [SSTK], scaled by average total assets [AT]

D Dummy variable with the value of 1 if $\mathrm{CFO}<0$ or $\triangle \mathrm{CFO}<0$

E Earnings before extraordinary items [IB] scaled by average total assets [AT]

EXPENSE Sales [SALE] minus earnings before extraordinary items [IB] scaled by average total assets $[\mathrm{AT}]$

MV Market value of equity [CSHO*PRCC_F] at fiscal year end

PctLoss Percentage of firms with negative earnings before extraordinary items [IB]

Std(OI-PTI) Cross-sectional standard deviation of the difference between operating income after depreciation [OIADP] and pre-tax income [PI]

SALE Net sales [SALE] scaled by average total assets [AT]

SG\&AINS SG\&A intensity measured as selling, general, and administrative expense [XSGA] scaled by total expenses, where total expenses are equal to sales [SALE] minus earnings before extraordinary items [IB]

TACC Total accruals calculated as changes in non-cash current assets [ACT-CHE] minus changes in non-debt current liabilities [LCT-DLC] minus depreciation expense [DP] scaled by average total assets [AT] from the beginning of the sample 
through 1987 and as earnings [IBC] minus cash flows from operations [OANCF], both as reported on the statement of cash flows and the difference scaled by average total assets $[\mathrm{AT}]$ from 1988 on

TACC_RSST Total accruals from Richardson, Sloan, Soliman, and Tuna (2005) calculated as changes in non-cash assets [AT-CHE] minus changes in liabilities [LT] scaled by average total assets $[\mathrm{AT}]$

Time Number of years since 1964/1965 
Figure 1

The relation between accruals and cash flows over time: Dechow (1994)

Panel A: Adjusted $\mathrm{R}^{2}$ and Coefficient on $\mathrm{CFO}_{\mathrm{t}}\left(\beta_{1}\right)-$ Levels Model: TACC $_{t}=\beta_{0}+\beta_{1} C F O_{t}+e_{t}$

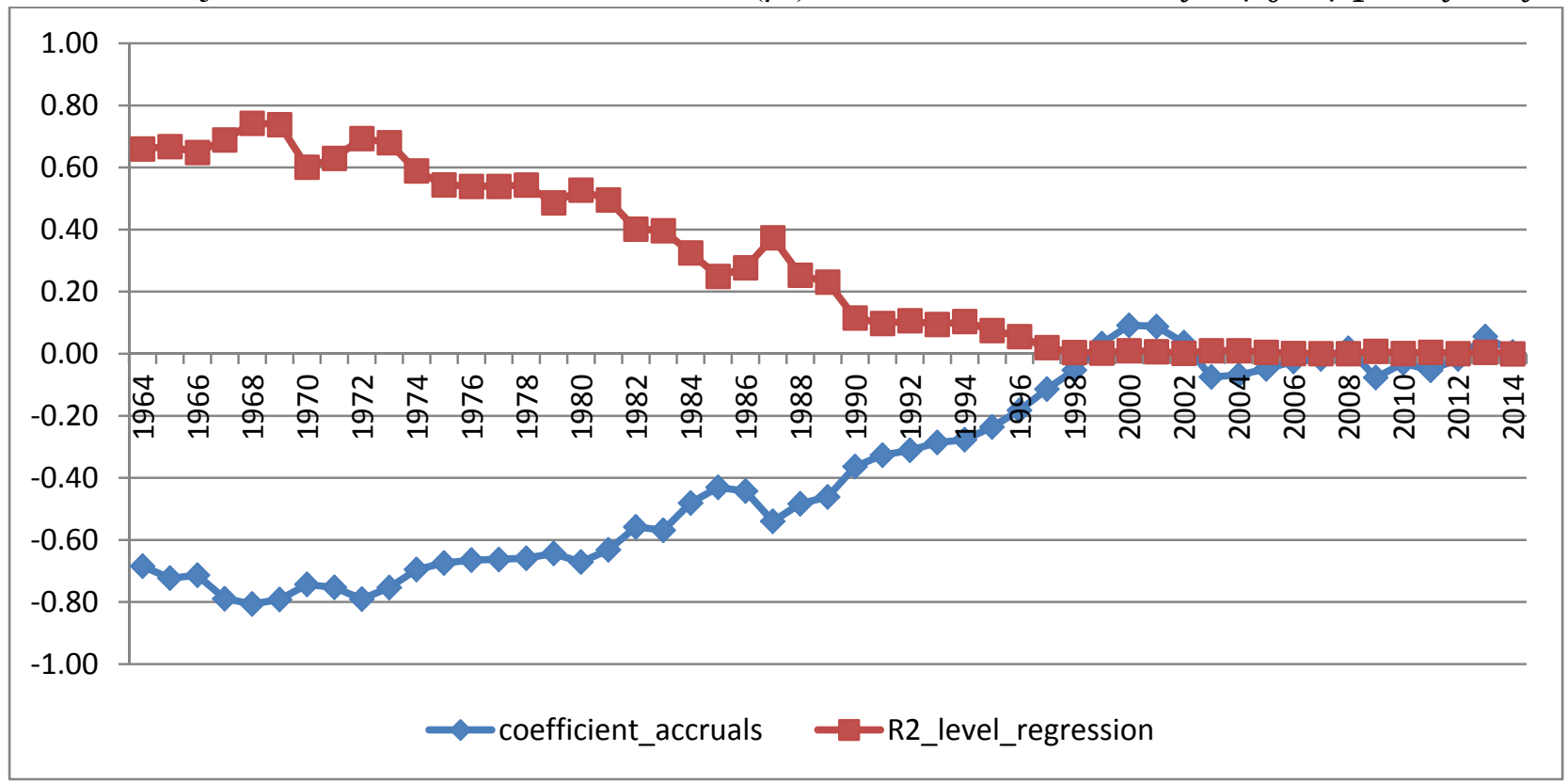

Panel B: Adjusted $\mathrm{R}^{2}$ and Coefficient $\beta_{1}-$ Changes Model: $\triangle T A C C_{t}=\beta_{0}+\beta_{1} \Delta C F O_{t}+e_{t}$

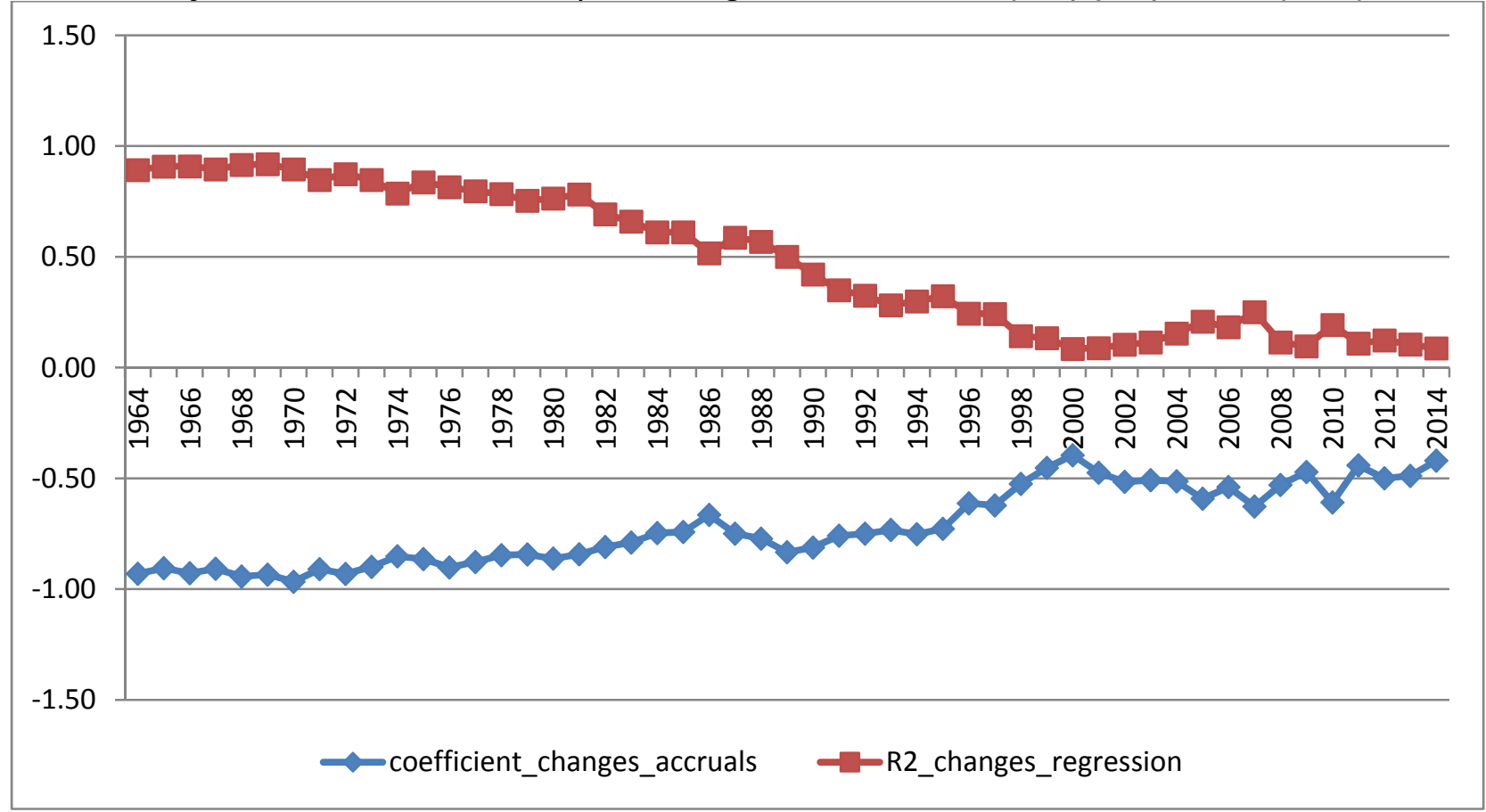

$T A C C_{t}$ is total accruals. $C F O_{t}$ is cash flows from operations. The sample includes 217,164 firm-year observations with non-missing $T_{A C C_{t}}$ and $C F O_{t}$ from 1964 to 2014. Each year, all variables are Winsorized at 1 percent and 99 percent. 
Figure 2

The relation between accruals and past, current, and future cash flows over time: Dechow and Dichev (2002)

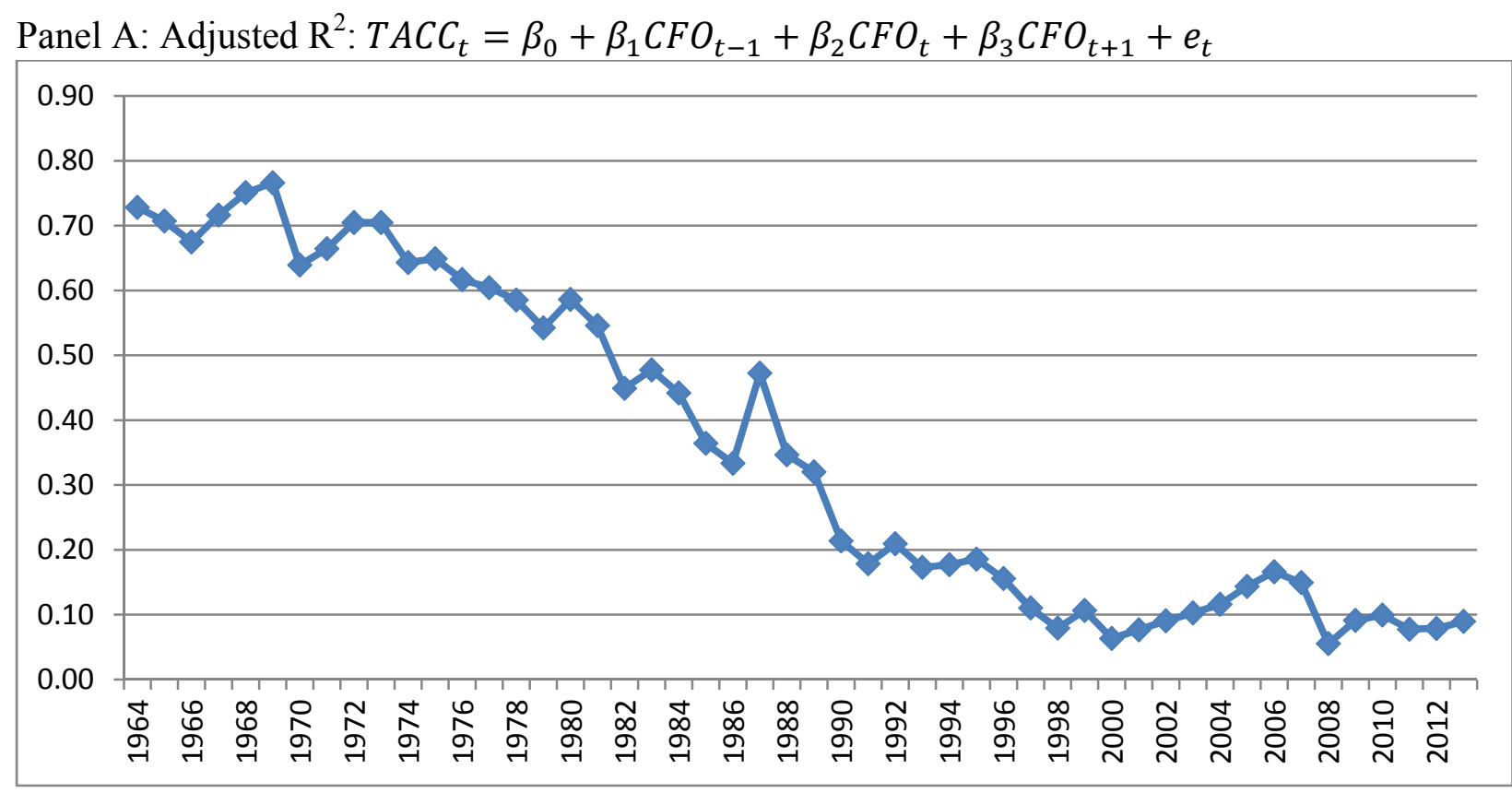

Panel B: Coefficients $\beta_{1} \beta_{2} \beta_{3}:$ TACC $C_{t}=\beta_{0}+\beta_{1} C F O_{t-1}+\beta_{2} C F O_{t}+\beta_{3} C F O_{t+1}+e_{t}$

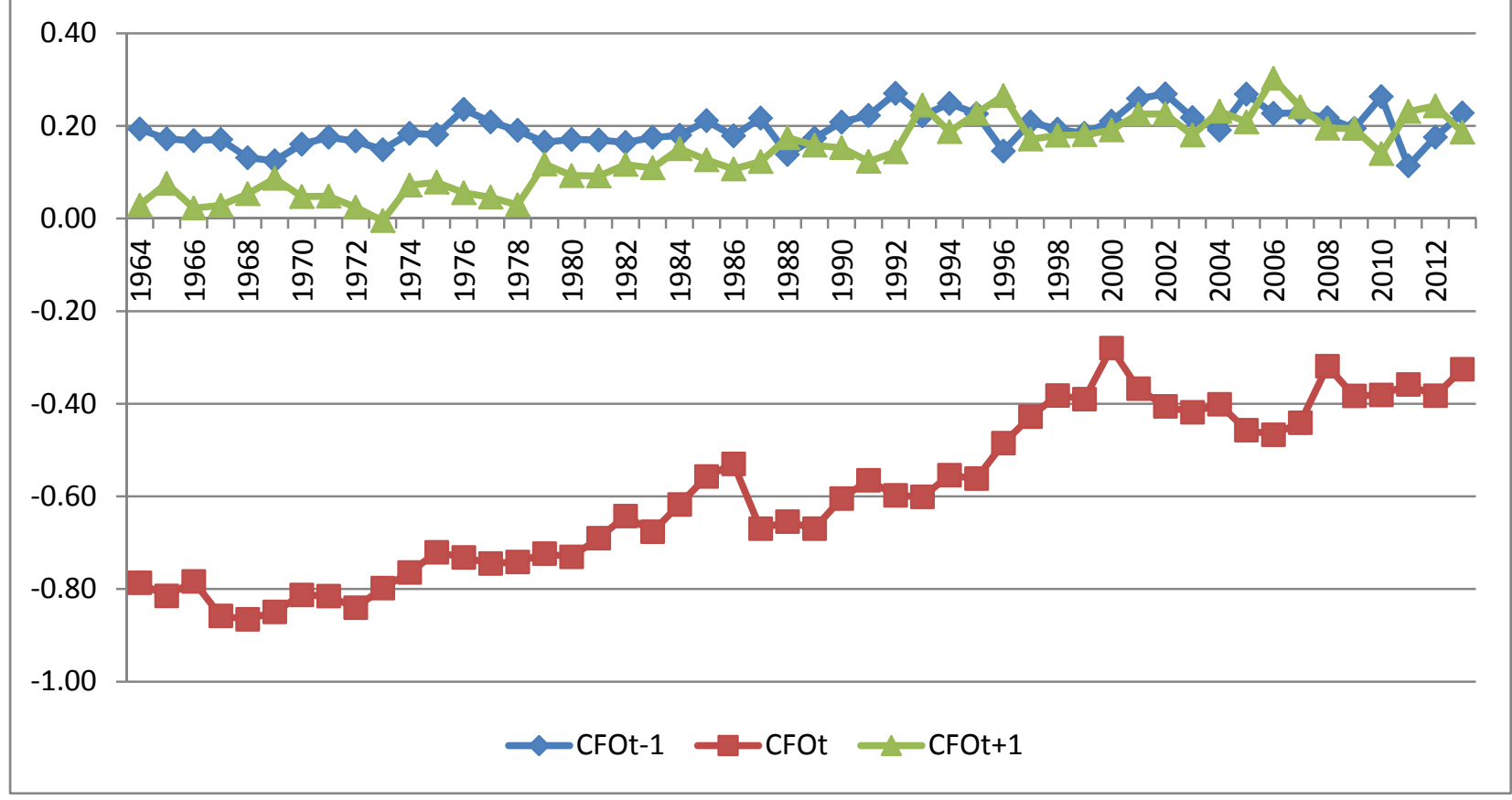

$T A C C_{t}$ is total accruals. $C F O_{t}$ is cash flows from operations. The full sample includes 159,932 firm-year observations with non-missing $T A C C_{t}, C F O_{t-1}, C F O_{t}$, and $C F O_{t+1}$ from 1964 to 2013. Each year, all variables are Winsorized at 1 percent and 99 percent. 
Figure 3

The timely loss recognition role of accruals over time: Ball and Shivakumar (2006)

Panel A: Adjusted $\mathrm{R}^{2}$ from TACC $_{t}=\beta_{0}+\beta_{1} C F O_{t}+\beta_{2} D+\beta_{3} D * C F O_{t}+e_{t}$, where $\mathrm{D}=1$ if $\mathrm{CFO}<0$.

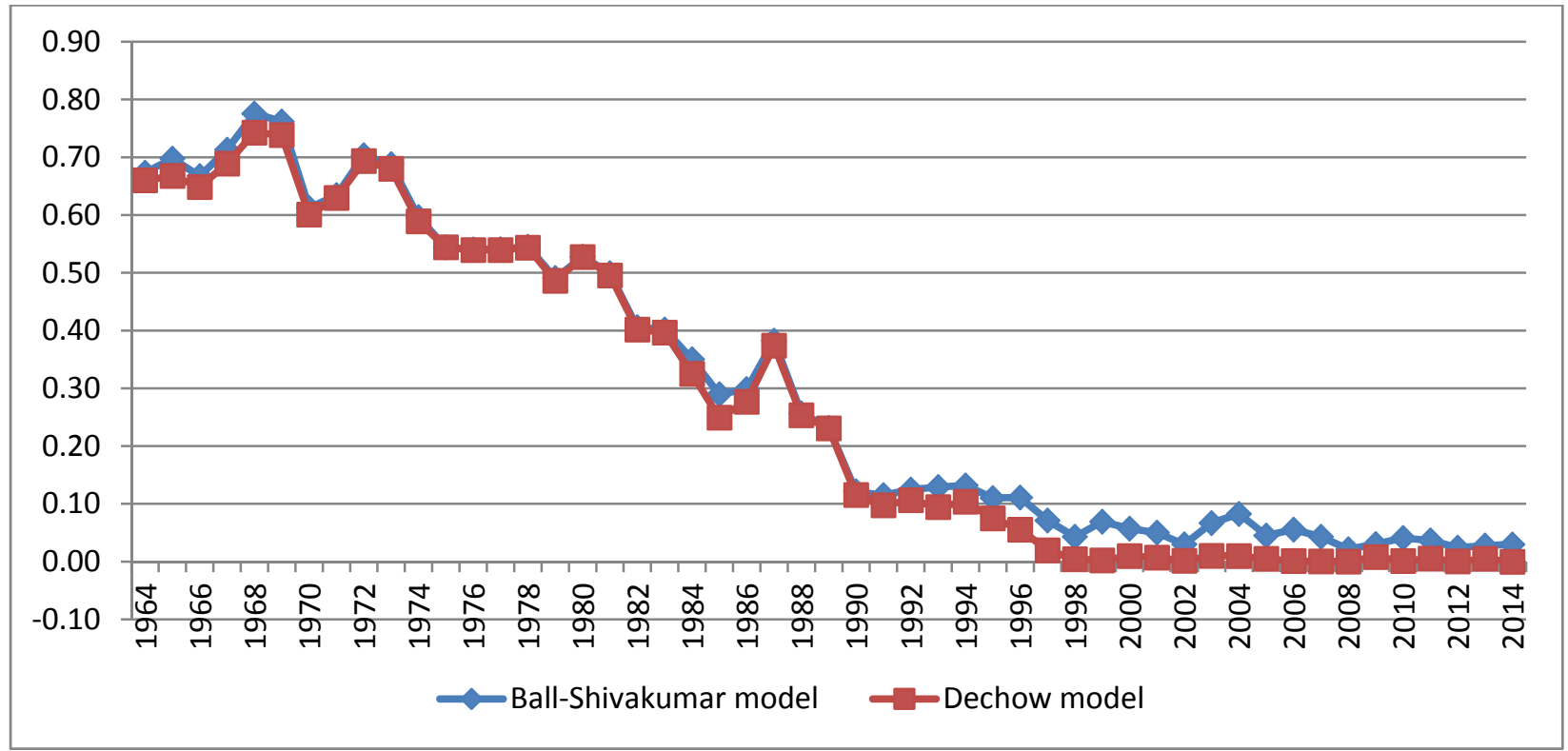

Panel B: Coefficient estimates from $\operatorname{TACC}_{t}=\beta_{0}+\beta_{1} C F O_{t}+\beta_{2} D+\beta_{3} D * C F O_{t}+e_{t}$, where $\mathrm{D}=1$ if $\mathrm{CFO}<0$.

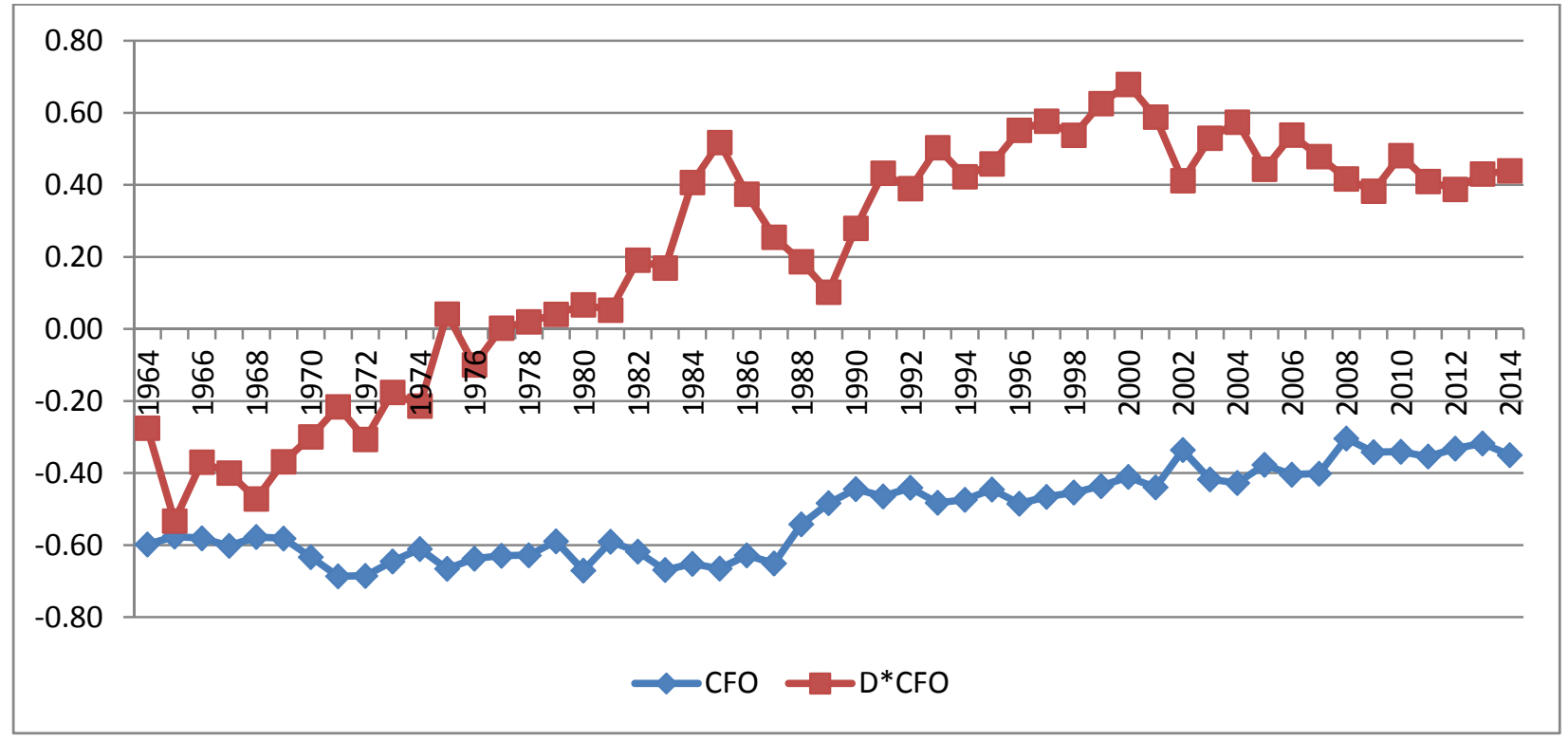


Panel C: Adjusted $\mathrm{R}^{2}$ from TACC $_{t}=\beta_{0}+\beta_{1} C F O_{t}+\beta_{2} D+\beta_{3} D * C F O_{t}+e_{t}$, where $\mathrm{D}=1$ if $\triangle \mathrm{CFO}<0$.

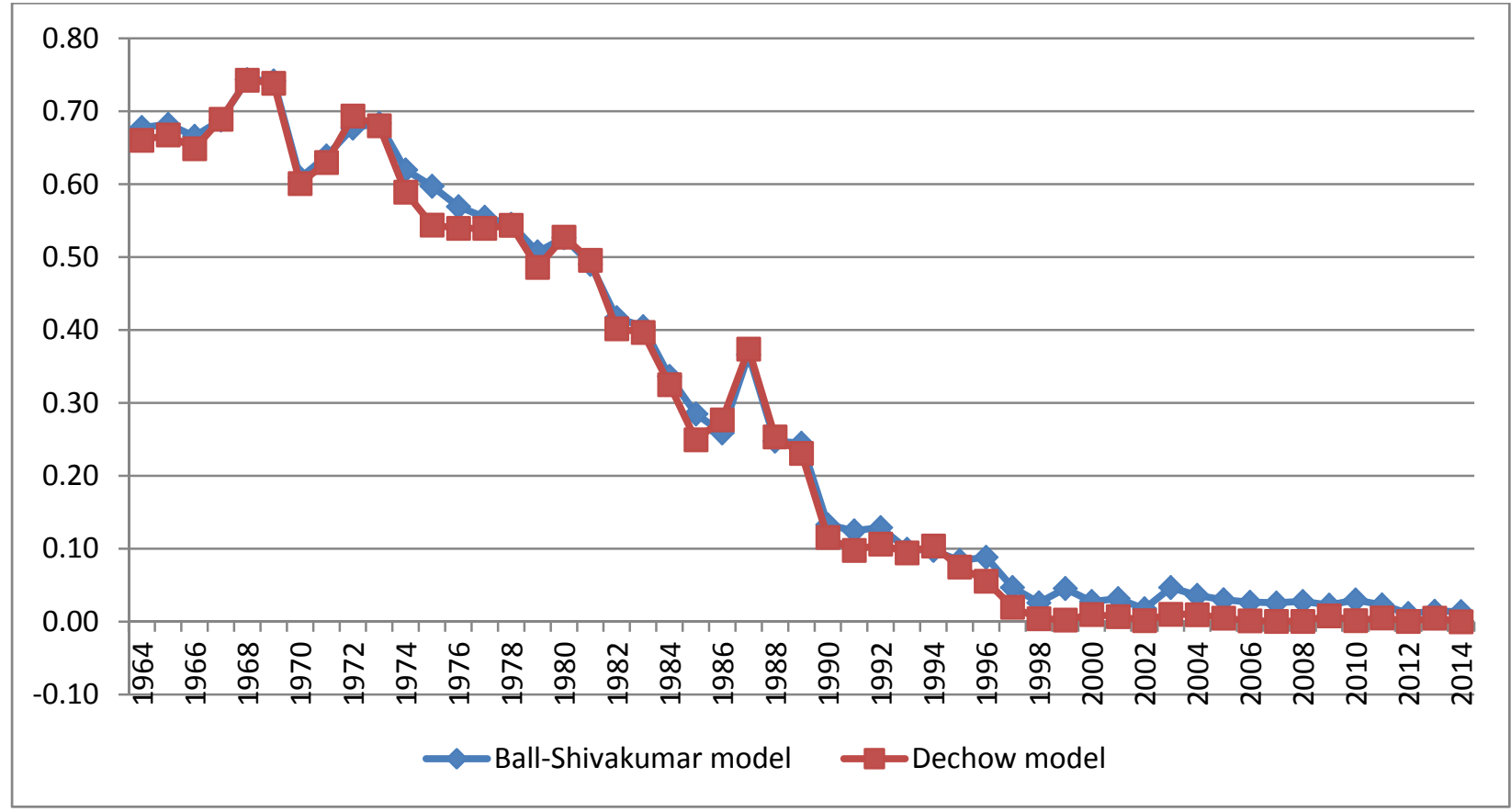

Panel D: Coefficient estimates from $\operatorname{TACC}_{t}=\beta_{0}+\beta_{1} C F O_{t}+\beta_{2} D+\beta_{3} D * C F O_{t}+e_{t}$, where $\mathrm{D}=1$ if $\triangle \mathrm{CFO}<0$.

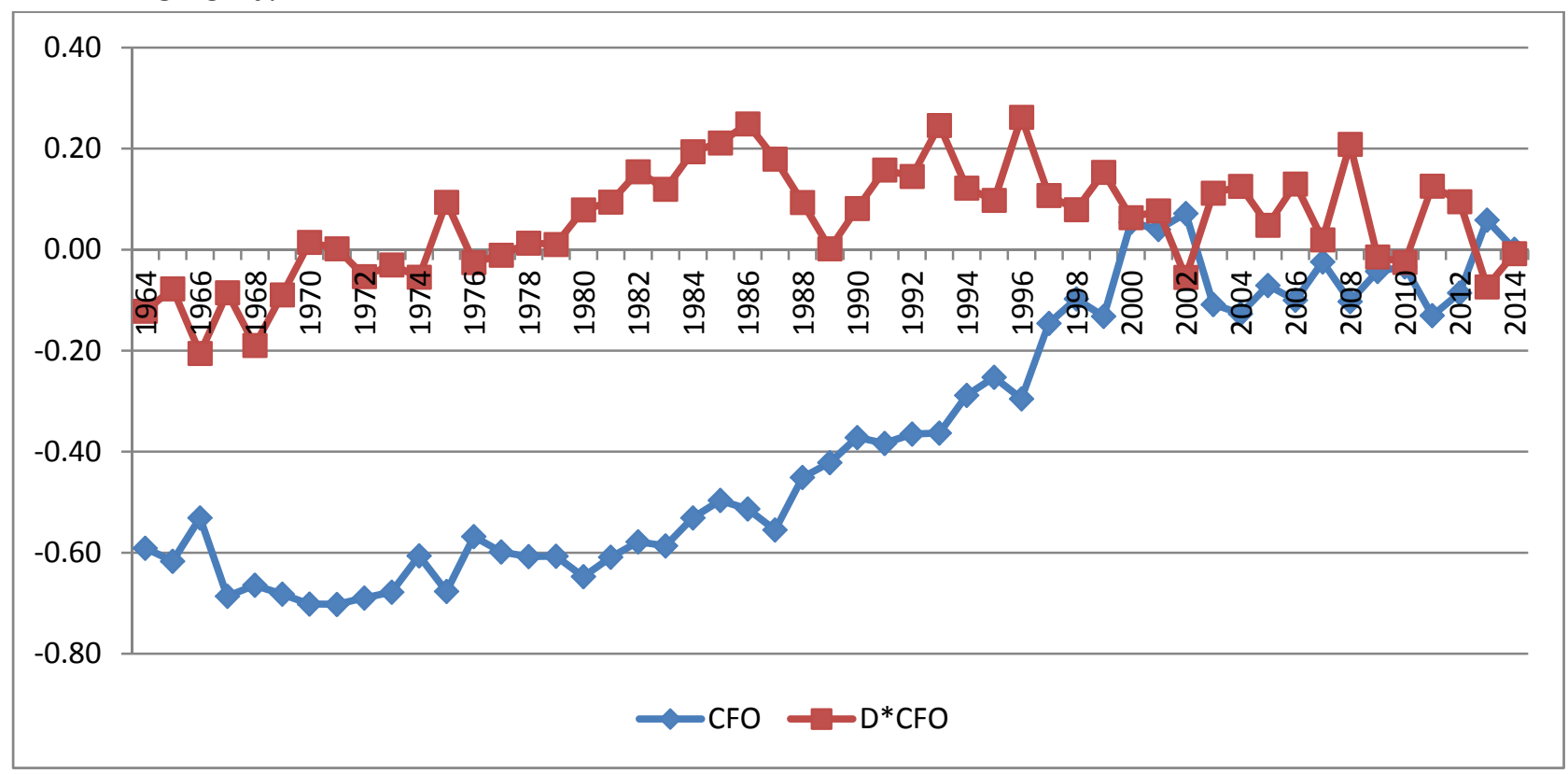

$T A C C_{t}$ is total accruals. $C F O_{t}$ is cash flows from operations. $D$ is a dummy variable with the value of 1 if $\triangle C F O_{t}$ is negative for Panels $\mathrm{A}$ and $\mathrm{B}$ and with the value of 1 if $C F O_{t}$ is negative for Panels $\mathrm{C}$ and $\mathrm{D}$. 
Figure 4

The adjusted $\mathbf{R}^{2}$ from the Dechow model for each wave of newly-listed firms

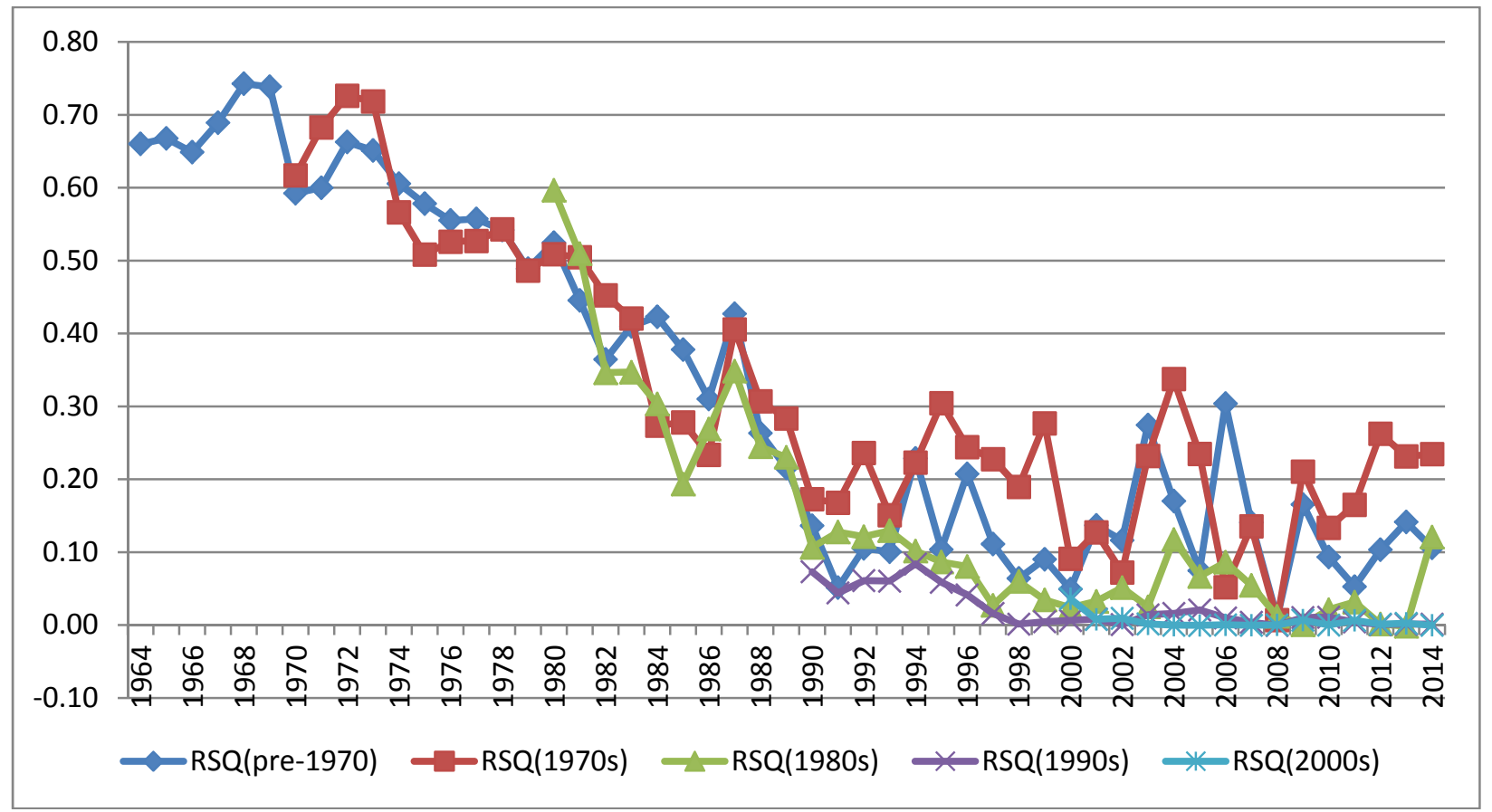

This figure reports the adjusted $\mathrm{R}^{2}$ of the Dechow (1994) model for firm-year observations from the successive listing cohorts in each year from 1964 to 2014. All of the firms are divided into five listing cohorts in the following steps. The first year in which a firm's data are available in Compustat is referred to as the "listing year". All of the firms with a listing year before 1970 are classified as "pre-1970". The remaining firms listed in a common decade are referred to as a wave of newly-listed firms in the $1970 \mathrm{~s}, 1980 \mathrm{~s}, 1990 \mathrm{~s}$, and $2000 \mathrm{~s}$. The adjusted $\mathrm{R}^{2}$ from the Dechow (1994) model is based on the regression: $T A C C_{t}=\beta_{0}+\beta_{1} C F O_{t}+e_{t}$, which is estimated annually for each cohort. $T A C C_{t}$ is total accruals. $C F O_{t}$ is cash flows from operations. The sample includes 217,164 firm-year observations with non-missing $T A C C_{t}$ and $C F O_{t}$ from 1964 to 2014. Each year, all variables are Winsorized at 1 percent and 99 percent. 
Figure 5

\section{A relatively constant sample: The levels model based on Dechow (1994)}

Panel A: Adjusted $\mathrm{R}^{2}$ of the Dechow model (Firms with at least 30 or 40 years' data)

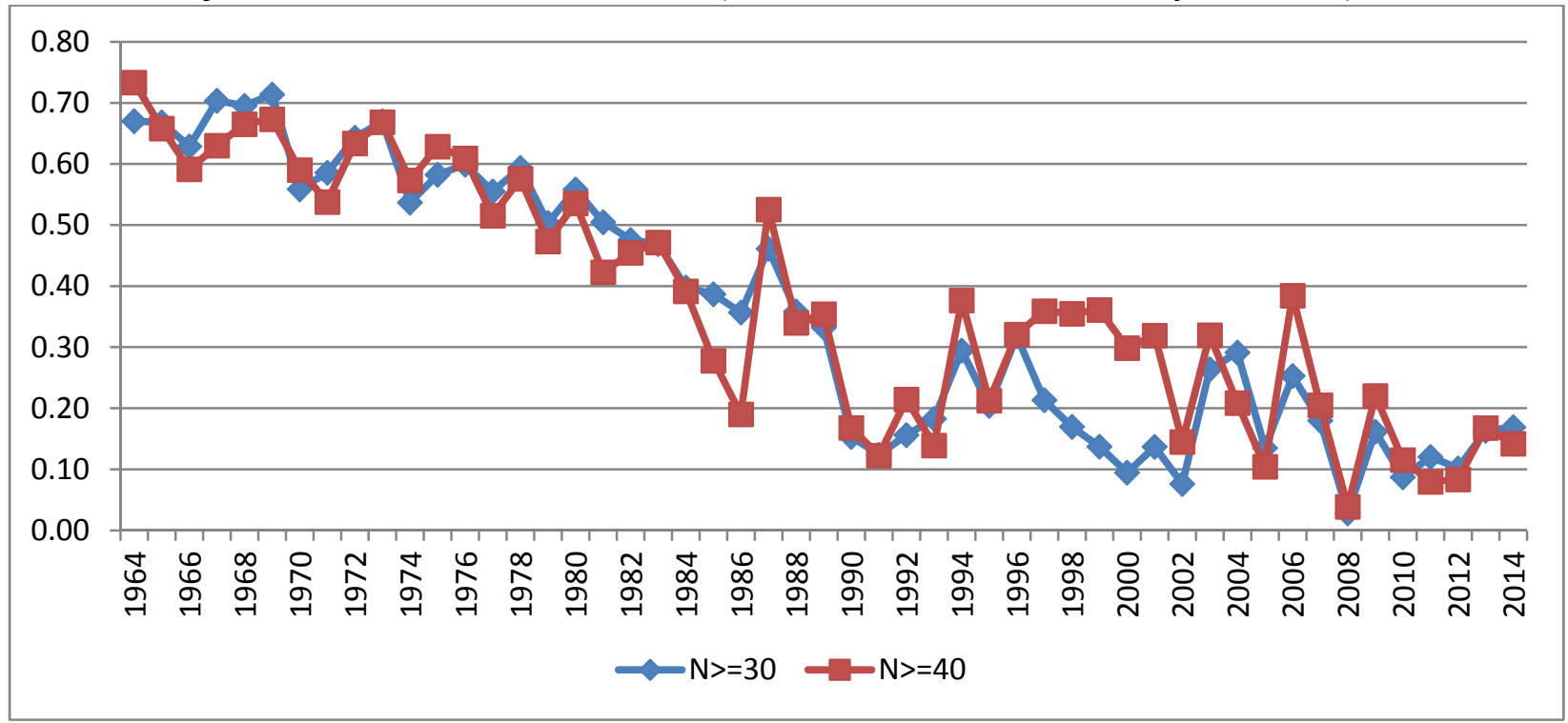

Panel B: Coefficient on $\mathrm{CFO}_{\mathrm{t}}\left(\beta_{1}\right)$ of the Dechow model (Firms with at least 30 or 40 years' data)

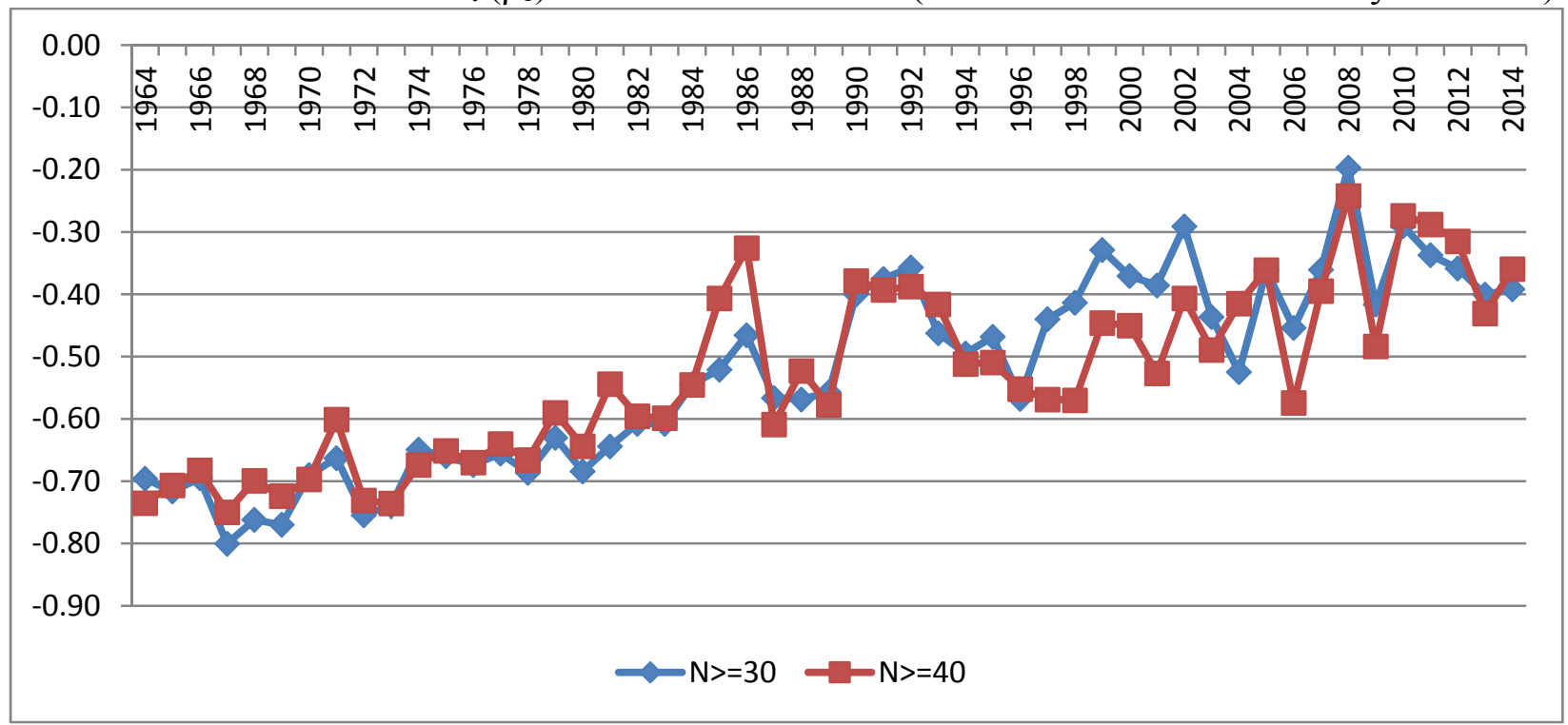

The adjusted $\mathrm{R}^{2}$ and coefficient estimate on CFO from the Dechow (1994) model is based on the regression: $T A C C_{t}=\beta_{0}+\beta_{1} C F O_{t}+e_{t}$, which is estimated annually for each subsample. $T A C C_{t}$ is total accruals. $C F O_{t}$ is cash flows from operations. There are on average 1,018 and 558 observations per year from 1964 to 2014 when we require at least 30 and 40 years' data for a firm to be included in these two subsamples, respectively, compared to 4,258 observations without such a requirement. 


\section{Table 1}

\section{Descriptive statistics}

Panel A: Descriptive statistics

\begin{tabular}{lrrrrrrrr}
\hline Variable & $\mathrm{N}$ & Mean & Stdev & Min & Q1 & Median & Q3 & Max \\
\hline$E_{t}$ & 217164 & -0.004 & 0.186 & -1.425 & -0.013 & 0.039 & 0.077 & 0.392 \\
$T A C C_{t}$ & 217164 & -0.054 & 0.129 & -1.717 & -0.093 & -0.045 & -0.001 & 1.249 \\
$C F O_{t-1}$ & 186109 & 0.055 & 0.145 & -0.904 & 0.013 & 0.074 & 0.127 & 0.420 \\
$C F O_{t}$ & 217164 & 0.050 & 0.153 & -0.904 & 0.008 & 0.072 & 0.127 & 0.420 \\
$C F O_{t+1}$ & 184881 & 0.056 & 0.144 & -0.904 & 0.015 & 0.075 & 0.128 & 0.420 \\
$M V_{t}$ & 189864 & 2139 & 12763 & 0 & 28 & 119 & 619 & 1819782 \\
$B M_{t}$ & 188999 & 0.724 & 1.549 & -47.674 & 0.321 & 0.597 & 1.032 & 10.825 \\
$S G \& A$ & 180566 & 0.268 & 0.216 & 0.001 & 0.119 & 0.210 & 0.346 & 1.905 \\
Intensity & & & & & & & & \\
\hline
\end{tabular}

Panel B: Correlation matrix for key variables. Pearson (Spearman) correlations are shown above (below) the main diagonal.

\begin{tabular}{lccrrr}
\hline & $E_{t}$ & $T A C C_{t}$ & \multicolumn{1}{c}{$C F O_{t-1}$} & \multicolumn{1}{c}{$C F O_{t}$} & \multicolumn{1}{c}{$C F O_{t+1}$} \\
\hline$E_{t}$ & & $0.58^{* *}$ & $0.63^{* *}$ & $0.72^{* *}$ & $0.62^{* *}$ \\
$T_{A C C_{t}}$ & $0.36^{* *}$ & & $0.10^{* *}$ & $-0.14^{* *}$ & $0.06^{* *}$ \\
$C F O_{t-1}$ & $0.52^{* *}$ & $-0.03^{* *}$ & & $0.56^{* *}$ & $0.60^{* *}$ \\
$C F O_{t}$ & $0.59^{* *}$ & $-0.39^{* *}$ & $0.68^{* *}$ & & $0.68^{* *}$ \\
$C F O_{t+1}$ & $0.46^{* *}$ & $-0.09^{* *}$ & $0.49^{* *}$ & $0.56^{* *}$ & \\
\hline
\end{tabular}

** Significant at the 1 percent level.

$E_{t}$ is earnings before extraordinary items scaled by average total assets. $T A C C_{t}$ is total accruals measured as working capital accruals minus depreciation expense scaled by average total assets prior to 1988 and as $E_{t}$ minus cash flows from operations from the statement of cash flows scaled by average total assets since 1988. $C F O_{t}$ is cash flows from operations measured as earnings minus total accruals prior to 1988 and as cash flows from operations from the statement of cash flows scaled by average total assets since 1988. $M V_{t}$ is the market value of equity at a firm's fiscal year end. $B M_{t}$ is the book-to-market ratio, calculated as the book value of equity scaled by the market value of equity at fiscal year-end. $S G \& A$ Intensity is SG\&A intensity measured as selling, general, and administrative expenses scaled by total expenses, where total expenses are equal to sales minus earnings before extraordinary items. The sample includes 217,164 firm-year observations with non-missing $T A C C_{t}$ and $C F O_{t}$ from 1964 to 2014 after excluding financial firms $(60<=\mathrm{SIC}<=69)$ and firm-years with large acquisitions (AQS over $5 \%$ of sales). Each year, all variables except for $M V_{t}$ are Winsorized at 1 percent and 99 percent. 
Table 2

The relation between accruals and cash flows over time: Dechow (1994)

Panel A: Regression model on levels: $T A C C_{t}=\beta_{0}+\beta_{1} C F O_{t}+e_{t}$

\begin{tabular}{cccccccc}
\hline Year & $\beta_{0}$ & $\beta_{1}\left(C F O_{t}\right)$ & Adj. $\mathrm{R}^{2}$ & year & $\beta_{0}$ & $\beta_{1}\left(C F O_{t}\right)$ & Adj. $\mathrm{R}^{2}$ \\
\hline 1964 & 0.04 & -0.68 & 0.66 & 1990 & -0.04 & -0.36 & 0.12 \\
1965 & 0.05 & -0.72 & 0.67 & 1991 & -0.05 & -0.33 & 0.10 \\
1966 & 0.06 & -0.71 & 0.65 & 1992 & -0.04 & -0.31 & 0.11 \\
1967 & 0.06 & -0.79 & 0.69 & 1993 & -0.04 & -0.29 & 0.09 \\
1968 & 0.06 & -0.81 & 0.74 & 1994 & -0.03 & -0.28 & 0.10 \\
1969 & 0.05 & -0.79 & 0.74 & 1995 & -0.03 & -0.24 & 0.07 \\
1970 & 0.03 & -0.74 & 0.60 & 1996 & -0.04 & -0.18 & 0.06 \\
1971 & 0.03 & -0.75 & 0.63 & 1997 & -0.06 & -0.11 & 0.02 \\
1972 & 0.04 & -0.79 & 0.69 & 1998 & -0.07 & -0.05 & 0.00 \\
1973 & 0.05 & -0.75 & 0.68 & 1999 & -0.07 & 0.03 & 0.00 \\
1974 & 0.04 & -0.70 & 0.59 & 2000 & -0.09 & 0.09 & 0.01 \\
1975 & 0.02 & -0.67 & 0.54 & 2001 & -0.13 & 0.09 & 0.01 \\
1976 & 0.03 & -0.67 & 0.54 & 2002 & -0.10 & 0.04 & 0.00 \\
1977 & 0.03 & -0.66 & 0.54 & 2003 & -0.07 & -0.08 & 0.01 \\
1978 & 0.04 & -0.66 & 0.54 & 2004 & -0.06 & -0.07 & 0.01 \\
1979 & 0.04 & -0.64 & 0.49 & 2005 & -0.06 & -0.05 & 0.00 \\
1980 & 0.03 & -0.67 & 0.53 & 2006 & -0.06 & -0.02 & 0.00 \\
1981 & 0.02 & -0.63 & 0.50 & 2007 & -0.07 & -0.02 & 0.00 \\
1982 & 0.00 & -0.56 & 0.40 & 2008 & -0.11 & 0.02 & 0.00 \\
1983 & 0.00 & -0.57 & 0.40 & 2009 & -0.09 & -0.08 & 0.01 \\
1984 & 0.01 & -0.48 & 0.33 & 2010 & -0.06 & -0.03 & 0.00 \\
1985 & -0.02 & -0.43 & 0.25 & 2011 & -0.06 & -0.05 & 0.01 \\
1986 & -0.01 & -0.44 & 0.28 & 2012 & -0.08 & -0.02 & 0.00 \\
1987 & 0.00 & -0.54 & 0.37 & 2013 & -0.09 & 0.06 & 0.00 \\
1988 & -0.01 & -0.48 & 0.25 & 2014 & -0.08 & 0.01 & 0.00 \\
1989 & -0.02 & -0.46 & 0.23 & & & & \\
\hline
\end{tabular}

Panel B: Regression model on changes: $\triangle T A C C_{t}=\beta_{0}+\beta_{1} \Delta C F O_{t}+e_{t}$

\begin{tabular}{cccccccc}
\hline Year & $\beta_{0}$ & $\beta_{1}\left(C F O_{t}\right)$ & Adj. $\mathrm{R}^{2}$ & year & $\beta_{0}$ & $\beta_{1}\left(C F O_{t}\right)$ & Adj. $\mathrm{R}^{2}$ \\
\hline 1964 & 0.01 & -0.93 & 0.89 & 1990 & -0.02 & -0.81 & 0.42 \\
1965 & 0.01 & -0.91 & 0.91 & 1991 & -0.01 & -0.76 & 0.35 \\
1966 & 0.00 & -0.93 & 0.91 & 1992 & 0.00 & -0.75 & 0.33 \\
1967 & -0.01 & -0.91 & 0.90 & 1993 & -0.01 & -0.73 & 0.28 \\
1968 & 0.00 & -0.94 & 0.92 & 1994 & 0.00 & -0.75 & 0.30 \\
1969 & -0.01 & -0.93 & 0.92 & 1995 & -0.01 & -0.73 & 0.32 \\
1970 & -0.02 & -0.97 & 0.89 & 1996 & -0.01 & -0.61 & 0.24 \\
1971 & 0.00 & -0.91 & 0.85 & 1997 & -0.01 & -0.62 & 0.24 \\
1972 & 0.01 & -0.93 & 0.87 & 1998 & -0.02 & -0.53 & 0.14 \\
1973 & 0.01 & -0.90 & 0.85 & 1999 & 0.00 & -0.45 & 0.13 \\
1974 & -0.01 & -0.85 & 0.79 & 2000 & -0.01 & -0.40 & 0.08 \\
1975 & -0.01 & -0.86 & 0.84 & 2001 & -0.04 & -0.47 & 0.09 \\
1976 & 0.01 & -0.90 & 0.81 & 2002 & 0.01 & -0.52 & 0.10
\end{tabular}




\begin{tabular}{lccccccc}
1977 & 0.00 & -0.88 & 0.80 & 2003 & 0.02 & -0.51 & 0.11 \\
1978 & 0.00 & -0.85 & 0.78 & 2004 & 0.01 & -0.51 & 0.15 \\
1979 & 0.00 & -0.84 & 0.75 & 2005 & 0.00 & -0.59 & 0.21 \\
1980 & -0.01 & -0.86 & 0.76 & 2006 & 0.00 & -0.54 & 0.18 \\
1981 & 0.00 & -0.84 & 0.78 & 2007 & -0.01 & -0.63 & 0.25 \\
1982 & -0.02 & -0.81 & 0.69 & 2008 & -0.04 & -0.53 & 0.11 \\
1983 & 0.00 & -0.79 & 0.66 & 2009 & 0.01 & -0.47 & 0.10 \\
1984 & 0.00 & -0.75 & 0.61 & 2010 & 0.03 & -0.61 & 0.19 \\
1985 & -0.02 & -0.74 & 0.61 & 2011 & 0.00 & -0.44 & 0.11 \\
1986 & -0.01 & -0.67 & 0.52 & 2012 & -0.02 & -0.50 & 0.12 \\
1987 & 0.00 & -0.75 & 0.59 & 2013 & 0.00 & -0.49 & 0.10 \\
1988 & -0.01 & -0.77 & 0.57 & 2014 & 0.00 & -0.42 & 0.09 \\
1989 & -0.01 & -0.83 & 0.50 & & & & \\
\hline
\end{tabular}

Panel C: Regression results for time trends in $\beta_{1}\left(C F O_{t}\right)$ and the adj. $\mathrm{R}^{2}$ for the levels model $\beta_{1}\left(C F O_{t}\right)=b_{0}+b_{1}$ Time $+\varepsilon$

\begin{tabular}{|c|c|c|c|c|c|}
\hline Regression & $\begin{array}{c}b_{0} \\
\text { (t-stat) }\end{array}$ & $\begin{array}{c}b_{1} \\
\text { (t-stat) }\end{array}$ & $\mathrm{R}^{2}$ & $\begin{array}{c}\text { Fitted value } \\
\text { year } 1964\end{array}$ & $\begin{array}{c}\text { Fitted value } \\
\text { year } 2014\end{array}$ \\
\hline$\beta_{1}\left(C F O_{t}\right)$ & $\begin{array}{c}-0.87 \\
(-33.93)\end{array}$ & $\begin{array}{l}0.0198 \\
(22.43)\end{array}$ & 0.909 & -0.870 & 0.120 \\
\hline Adj. $R^{2}$ & $\begin{array}{c}0.718 \\
(30.88) \\
\end{array}$ & $\begin{array}{l}-0.0176 \\
(-21.89) \\
\end{array}$ & 0.905 & 0.718 & -0.162 \\
\hline
\end{tabular}

Panel D: Regression results for time trends in $\beta_{1}\left(\triangle C F O_{t}\right)$ and the adj. $\mathrm{R}^{2}$ for the changes model $\beta_{1}\left(\triangle C F O_{t}\right)=b_{0}+b_{1}$ Time $+\varepsilon$ Adj. $R^{2}=b_{0}+b_{1}$ Time $+\varepsilon$

\begin{tabular}{cccccc}
\multicolumn{6}{c}{ Adj. $R^{2}=b_{0}+b_{1}$ Time $+\varepsilon$} \\
Regression & $\begin{array}{c}b_{0} \\
(\mathrm{t}-\mathrm{stat})\end{array}$ & $\begin{array}{c}b_{1} \\
(\mathrm{t}-\mathrm{stat})\end{array}$ & $\mathrm{R}^{2}$ & $\begin{array}{c}\text { Fitted value } \\
\text { year 1964 }\end{array}$ & $\begin{array}{c}\text { Fitted value } \\
\text { year 2014 }\end{array}$ \\
\hline$\beta_{1}\left(\Delta C F O_{t}\right)$ & -0.988 & 0.011 & & & \\
& $(-54.31)$ & $(17.20)$ & 0.855 & -0.998 & -0.438 \\
Adj. $R^{2}$ & 0.993 & -0.020 & & & \\
\hline
\end{tabular}

$T A C C_{t}$ is total accruals. $C F O_{t}$ is cash flows from operations. Time is the number of years since 1964. In Panel C $\beta_{1}\left(C_{F O}\right)$ and $A d j . R^{2}$ are the coefficient estimate and the adjusted $\mathrm{R}^{2}$ respectively from the levels Dechow (1994) model $T A C C_{t}=\beta_{0}+\beta_{1} C F O_{t}+e_{t}$ estimated annually. In Panel D $\beta_{1}\left(\triangle C F O_{t}\right)$ and $A d j . R^{2}$ are the coefficient estimate and the adjusted $\mathrm{R}^{2}$ respectively from the changes Dechow (1994) model $\triangle T A C C_{t}=\beta_{0}+\beta_{1} \Delta C F O_{t}+$ $e_{t}$ estimated annually. The sample includes 217,164 firm-year observations with non-missing $T A C C_{t}$ and $C F O_{t}$ from 1964 to 2014. Each year, all variables are Winsorized at 1 percent and 99 percent. In Panels C and D, t-statistics in parentheses are adjusted for Newey-West autocorrelations of three lags. 
Table 3

The relation between accruals and past, current, and future cash flows over time: Dechow and Dichev (2002)

Panel A: Regression model: TACC $_{t}=\beta_{0}+\beta_{1} C F O_{t-1}+\beta_{2} C F O_{t}+\beta_{3} C F O_{t+1}+e_{t}$

\begin{tabular}{|c|c|c|c|c|c|}
\hline year & Intercept & $C F O_{t-1}$ & $\mathrm{CFO}_{t}$ & $C F O_{t+1}$ & Adj. $R^{2}$ \\
\hline 1964 & 0.03 & 0.19 & -0.79 & 0.03 & 0.73 \\
\hline 1965 & 0.04 & 0.17 & -0.82 & 0.08 & 0.71 \\
\hline 1966 & 0.05 & 0.17 & -0.78 & 0.02 & 0.67 \\
\hline 1967 & 0.04 & 0.17 & -0.86 & 0.03 & 0.72 \\
\hline 1968 & 0.04 & 0.13 & -0.87 & 0.05 & 0.75 \\
\hline 1969 & 0.04 & 0.12 & -0.85 & 0.09 & 0.77 \\
\hline 1970 & 0.02 & 0.16 & -0.81 & 0.05 & 0.64 \\
\hline 1971 & 0.02 & 0.18 & -0.82 & 0.05 & 0.66 \\
\hline 1972 & 0.03 & 0.17 & -0.84 & 0.02 & 0.70 \\
\hline 1973 & 0.04 & 0.15 & -0.80 & 0.00 & 0.70 \\
\hline 1974 & 0.03 & 0.18 & -0.76 & 0.07 & 0.64 \\
\hline 1975 & 0.01 & 0.18 & -0.72 & 0.08 & 0.65 \\
\hline 1976 & 0.01 & 0.24 & -0.73 & 0.06 & 0.62 \\
\hline 1977 & 0.02 & 0.21 & -0.74 & 0.05 & 0.60 \\
\hline 1978 & 0.03 & 0.19 & -0.74 & 0.03 & 0.59 \\
\hline 1979 & 0.02 & 0.16 & -0.72 & 0.12 & 0.54 \\
\hline 1980 & 0.01 & 0.17 & -0.73 & 0.09 & 0.59 \\
\hline 1981 & 0.01 & 0.17 & -0.69 & 0.09 & 0.55 \\
\hline 1982 & -0.02 & 0.16 & -0.64 & 0.12 & 0.45 \\
\hline 1983 & -0.01 & 0.18 & -0.68 & 0.11 & 0.48 \\
\hline 1984 & -0.01 & 0.18 & -0.62 & 0.15 & 0.44 \\
\hline 1985 & -0.03 & 0.21 & -0.56 & 0.13 & 0.36 \\
\hline 1986 & -0.03 & 0.18 & -0.53 & 0.11 & 0.33 \\
\hline 1987 & -0.01 & 0.22 & -0.67 & 0.12 & 0.47 \\
\hline 1988 & -0.01 & 0.14 & -0.65 & 0.17 & 0.35 \\
\hline 1989 & -0.02 & 0.17 & -0.67 & 0.16 & 0.32 \\
\hline 1990 & -0.04 & 0.21 & -0.60 & 0.15 & 0.21 \\
\hline 1991 & -0.05 & 0.22 & -0.57 & 0.12 & 0.18 \\
\hline 1992 & -0.05 & 0.27 & -0.60 & 0.14 & 0.21 \\
\hline 1993 & -0.05 & 0.22 & -0.60 & 0.24 & 0.17 \\
\hline 1994 & -0.04 & 0.25 & -0.55 & 0.19 & 0.18 \\
\hline 1995 & -0.04 & 0.23 & -0.56 & 0.23 & 0.19 \\
\hline 1996 & -0.05 & 0.15 & -0.49 & 0.27 & 0.16 \\
\hline 1997 & -0.06 & 0.21 & -0.43 & 0.17 & 0.11 \\
\hline 1998 & -0.07 & 0.19 & -0.38 & 0.18 & 0.08 \\
\hline 1999 & -0.06 & 0.18 & -0.39 & 0.18 & 0.11 \\
\hline 2000 & -0.08 & 0.21 & -0.28 & 0.19 & 0.06 \\
\hline
\end{tabular}




\begin{tabular}{llllll}
2001 & -0.11 & 0.26 & -0.37 & 0.23 & 0.08 \\
2002 & -0.10 & 0.27 & -0.41 & 0.23 & 0.09 \\
2003 & -0.07 & 0.22 & -0.42 & 0.18 & 0.10 \\
2004 & -0.06 & 0.19 & -0.40 & 0.23 & 0.12 \\
2005 & -0.06 & 0.27 & -0.46 & 0.21 & 0.14 \\
2006 & -0.06 & 0.23 & -0.47 & 0.30 & 0.17 \\
2007 & -0.06 & 0.23 & -0.44 & 0.24 & 0.15 \\
2008 & -0.10 & 0.22 & -0.32 & 0.19 & 0.06 \\
2009 & -0.09 & 0.19 & -0.38 & 0.19 & 0.09 \\
2010 & -0.06 & 0.26 & -0.38 & 0.14 & 0.10 \\
2011 & -0.06 & 0.11 & -0.36 & 0.23 & 0.08 \\
2012 & -0.07 & 0.18 & -0.38 & 0.24 & 0.08 \\
2013 & -0.08 & 0.23 & -0.33 & 0.19 & 0.09 \\
\hline
\end{tabular}

Panel B: Regression results for time trends in $\beta(C F O)$ and adj. $\mathrm{R}^{2}$

\begin{tabular}{|c|c|c|c|c|c|}
\hline Regression & $\begin{array}{c}b_{0} \\
\text { (t-stat) }\end{array}$ & $\begin{array}{c}b_{1} \\
\text { (t-stat) } \\
\end{array}$ & $\mathrm{R}^{2}$ & $\begin{array}{c}\text { Fitted value } \\
\text { year } 1965\end{array}$ & $\begin{array}{c}\text { Fitted value } \\
\text { year } 2011\end{array}$ \\
\hline$\beta_{1}\left(C F O_{t-1}\right)$ & $\begin{array}{c}0.164 \\
(17.47)\end{array}$ & $\begin{array}{l}0.001 \\
(3.75)\end{array}$ & 0.210 & 0.164 & 0.214 \\
\hline$\beta_{2}\left(C F O_{t}\right)$ & $\begin{array}{c}-0.871 \\
(-56.22)\end{array}$ & $\begin{array}{c}0.011 \\
(20.87)\end{array}$ & 0.899 & -0.871 & -0.321 \\
\hline$\beta_{3}\left(C F O_{t+1}\right)$ & $\begin{array}{l}0.026 \\
(2.49)\end{array}$ & $\begin{array}{c}0.005 \\
(12.48)\end{array}$ & 0.760 & 0.026 & 0.276 \\
\hline Adj. $R^{2}$ & $\begin{array}{c}0.763 \\
(36.17) \\
\end{array}$ & $\begin{array}{c}-0.016 \\
(-22.16) \\
\end{array}$ & 0.909 & 0.763 & -0.037 \\
\hline
\end{tabular}

$T A C C_{t}$ is total accruals. $C F O_{t}$ is cash flows from operations. Time is the number of years since 1964. $\beta_{1}\left(C F O_{t-1}\right), \beta_{2}\left(C F O_{t}\right), \beta_{3}\left(C F O_{t+1}\right)$ and $A d j . R^{2}$ are the coefficient estimates and the adjusted $\mathrm{R}^{2}$ respectively from the Dechow and Dichev (2002) model TACC ${ }_{t}=\beta_{0}+\beta_{1} C F O_{t-1}+\beta_{2} C F O_{t}+\beta_{3} C F O_{t+1}+e_{t}$ estimated annually. The sample includes 159,932 firm-year observations with non-missing $T A C C_{t}, C F O_{t-1}, C F O_{t}$ and $C F O_{t+1}$ from 1964 to 2013. Each year, all variables are Winsorized at 1 percent and 99 percent. In Panel B, t-statistics in parentheses are adjusted for Newey-West autocorrelations of three lags. 
Table 4

\section{The impact of a temporal change in economic-based cash flow shocks and non-timing-} related accruals

\begin{tabular}{|c|c|c|c|c|c|c|}
\hline Regression & 1 & 2 & 3 & 4 & 5 & 6 \\
\hline Intercept & $\begin{array}{c}0.763 \\
(36.17)\end{array}$ & $\begin{array}{l}0.554 \\
(3.63)\end{array}$ & $\begin{array}{c}0.777 \\
(40.57)\end{array}$ & $\begin{array}{l}0.993 \\
(1.01)\end{array}$ & $\begin{array}{l}0.932 \\
(7.22)\end{array}$ & $\begin{array}{l}5.322 \\
(4.41)\end{array}$ \\
\hline Time & $\begin{array}{c}-0.016 \\
(-22.16)\end{array}$ & $\begin{array}{l}-0.014 \\
(-7.78)\end{array}$ & $\begin{array}{l}-0.006 \\
(-3.54)\end{array}$ & $\begin{array}{l}-0.017 \\
(-9.39)\end{array}$ & $\begin{array}{l}-0.012 \\
(-3.54)\end{array}$ & $\begin{array}{l}-0.006 \\
(-2.02)\end{array}$ \\
\hline $\operatorname{Std}(\mathrm{CFO})$ & & $\begin{array}{l}-0.080 \\
(-0.12)\end{array}$ & & & & $\begin{array}{l}-0.227 \\
(-0.27)\end{array}$ \\
\hline Auto_ $\triangle \mathrm{CFO}$ & & $\begin{array}{l}-0.412 \\
(-1.68)\end{array}$ & & & & $\begin{array}{l}-0.278 \\
(-1.54)\end{array}$ \\
\hline Std(OI-PTI) & & & $\begin{array}{l}-0.011 \\
(-0.01)\end{array}$ & & & $\begin{array}{l}-2.264 \\
(-2.05)\end{array}$ \\
\hline PctLoss & & & $\begin{array}{l}-1.098 \\
(-3.77)\end{array}$ & & & $\begin{array}{l}-0.657 \\
(-2.18)\end{array}$ \\
\hline Adj.R²(Dichev_Tang) & & & & $\begin{array}{l}-0.226 \\
(-0.23)\end{array}$ & & $\begin{array}{l}-4.335 \\
(-3.85)\end{array}$ \\
\hline SG\&A Intensity & & & & & $\begin{array}{l}-1.109 \\
(-1.32)\end{array}$ & $\begin{array}{l}-1.655 \\
(-1.48)\end{array}$ \\
\hline Adj. $\mathrm{R}^{2}$ & 0.909 & 0.912 & 0.947 & 0.907 & 0.910 & 0.958 \\
\hline
\end{tabular}

The dependent variable is the adjusted $\mathrm{R}^{2}$ from the Dechow-Dichev (2002) model, a proxy for the degree of the association between accruals and cash flows. Time is the number of years since 1964. Std(CFO) is the standard deviation of cash flows. Auto_ $\triangle C F O$ is the lag one autocorrelation of changes in cash flows. Std(OI-PTI) is the standard deviation of the difference between operating income after depreciation and pre-tax income, which proxies for the effect of one-time items and nonoperating income on the attenuation of the correlation between accruals and cash flows. PctLoss is the percentage of firms with negative earnings before extraordinary items.

Adj. $R^{2}$ (Dichev_Tang) is the adjusted $\mathrm{R}^{2}$ from the Dichev-Tang (2008) model, a proxy for the matching between revenue and expenses. $S G \& A$ Intensity is SG\&A intensity measured as selling, general, and administrative expenses scaled by total expenses, where total expenses are equal to sales minus earnings before extraordinary items.

Dechow-Dichev model: TACC $_{t}=\beta_{0}+\beta_{1} C F O_{t-1}+\beta_{2} C F O_{t}+\beta_{3} C F O_{t+1}+e_{t}$ Dichev-Tang model: $S_{A L E}=\beta_{0}+\beta_{1}$ EXPENSE $_{t-1}+\beta_{2}$ EXPENSE $_{t}+\beta_{3}$ EXPENSE $_{t+1}+e_{t}$ where $T A C C_{t}$ is total accruals. $C F O_{t}$ is cash flows from operations. $S A L E_{t}$ is net sales scaled by average total assets. EXPENSE $E_{t}$ is expenses measured as sales minus earnings before extraordinary items scaled by average total assets. The sample includes 159,932 firm-year observations with non-missing $T A C C_{t}, C F O_{t-1}, C F O_{t}$ and $C F O_{t+1}$ from 1964 to 2013. Each year, accruals and cash flow variables are Winsorized at 1 percent and 99 percent. T-statistics in parentheses are adjusted for Newey-West autocorrelations of three lags. 


\section{Table 5}

\section{The relation between accruals and cash flows using firm-specific time-series regressions}

Panel A: Summary statistics of equation (1a)

\begin{tabular}{|c|c|c|c|c|c|c|}
\hline & $\mathrm{N}$ & Mean & Stdev & Q1 & Median & Q3 \\
\hline Time Period & \multicolumn{6}{|c|}{ Summary statistics of the adjusted $\mathrm{R}^{2}$} \\
\hline 1964-1975 & 2654 & 0.732 & 0.271 & 0.610 & 0.839 & 0.931 \\
\hline 1976-1987 & 4143 & 0.590 & 0.358 & 0.340 & 0.713 & 0.890 \\
\hline 1988-1999 & 5373 & 0.367 & 0.391 & -0.005 & 0.373 & 0.730 \\
\hline \multirow[t]{2}{*}{$2000-2014$} & 7053 & 0.244 & 0.357 & -0.062 & 0.156 & 0.535 \\
\hline & \multicolumn{6}{|c|}{ Summary statistics of the $\mathrm{CFO}_{\mathrm{t}}$ coefficient estimates } \\
\hline $1964-1975$ & 2654 & -0.856 & 0.273 & -1.025 & -0.911 & -0.720 \\
\hline 1976-1987 & 4143 & -0.736 & 0.382 & -0.975 & -0.815 & -0.544 \\
\hline 1988-1999 & 5373 & -0.573 & 0.711 & -0.947 & -0.654 & -0.244 \\
\hline 2000-2014 & 7053 & -0.391 & 1.212 & -0.827 & -0.426 & -0.010 \\
\hline
\end{tabular}

Panel B: Summary statistics of equation (2)

$\begin{array}{llllll}\mathrm{N} & \text { Mean } & \text { Stdev } & \text { Q1 } & \text { Median } & \text { Q3 }\end{array}$

Time Period Summary statistics of the adjusted $\mathrm{R}^{2}$

\begin{tabular}{lllllll}
\hline $1964-1975$ & 1918 & 0.801 & 0.221 & 0.727 & 0.880 & 0.948 \\
$1976-1987$ & 2907 & 0.678 & 0.348 & 0.552 & 0.797 & 0.925 \\
$1988-1999$ & 3316 & 0.487 & 0.440 & 0.226 & 0.602 & 0.839 \\
$2000-2014$ & 4781 & 0.356 & 0.462 & 0.045 & 0.421 & 0.730 \\
\hline & \multicolumn{7}{l}{ Summary statistics of the CFO $\mathrm{CH}_{\mathrm{t}-1}$ coefficient estimates } & & \\
$1964-1975$ & 1918 & 0.139 & 0.237 & 0.003 & 0.119 & 0.260 \\
$1976-1987$ & 2907 & 0.135 & 3.636 & -0.006 & 0.125 & 0.287 \\
$1988-1999$ & 3316 & 0.138 & 2.151 & -0.081 & 0.126 & 0.354 \\
$2000-2014$ & 4781 & 0.108 & 13.671 & -0.102 & 0.139 & 0.421 \\
\hline
\end{tabular}




\begin{tabular}{lcccccc}
\hline \multicolumn{7}{c}{ Summary statistics of the $\mathrm{CFO}_{\mathrm{t}}$ coefficient estimates } \\
\cline { 2 - 6 } $1964-1975$ & 1918 & -0.865 & 0.279 & -1.024 & -0.903 & -0.725 \\
$1976-1987$ & 2907 & -0.736 & 1.277 & -0.980 & -0.812 & -0.558 \\
$1988-1999$ & 3316 & -0.652 & 2.731 & -0.998 & -0.744 & -0.397 \\
$2000-2014$ & 4781 & -0.495 & 2.422 & -0.918 & -0.574 & -0.137 \\
\hline & & & & & \\
$1964-1975$ & 1918 & -0.013 & 0.212 & -0.122 & -0.021 & 0.092 \\
$1976-1987$ & 2907 & 0.129 & 2.882 & -0.085 & 0.043 & 0.188 \\
$1988-1999$ & 3316 & 0.068 & 1.623 & -0.137 & 0.061 & 0.289 \\
$2000-2014$ & 4781 & 0.139 & 6.599 & -0.140 & 0.098 & 0.394 \\
\hline
\end{tabular}

$T A C C_{t}$ is total accruals. $C F O_{t}$ is cash flows from operations. We break our sample periods into four subperiods: 1964-1975, 1976-1987, 1988-1999, and 2000-2014. Then for each subperiod, we estimate the following two models for each firm using firm-specific time-series regressions, with a minimum of five and eight observations for Equations (1a) and (2), respectively.

$$
\begin{aligned}
& \text { Equation (1a): } \text { TACC }_{t}=\beta_{0}+\beta_{1} C F O_{t}+e_{t} \\
& \text { Equation (2): } \text { TACC }_{t}=\beta_{0}+\beta_{1} C F O_{t-1}+\beta_{2} C F O_{t}+\beta_{3} C F O_{t+1}+e_{t}
\end{aligned}
$$

The table reports summary statistics of the $C F O$ coefficient estimates and the adjusted $\mathrm{R}^{2}$ from these two models. The sample includes 217,164 firm-year observations with non-missing $T A C C_{t}$ and $C F O_{t}$ from 1964 to 2014. Each year, all variables are Winsorized at 1 percent and 99 percent. 
Table 6

The changing sample - cohorts of newly-listed firms in each decade

\begin{tabular}{|c|c|c|c|c|c|c|c|c|c|c|}
\hline \multirow[t]{2}{*}{ Year } & \multicolumn{5}{|c|}{ Number of firms } & \multicolumn{5}{|c|}{ Adjusted $\mathrm{R}^{2}$ from the Dechow model } \\
\hline & $\begin{array}{l}\text { Pre- } \\
1970 \\
\end{array}$ & $\begin{array}{l}1970 \mathrm{~s} \\
\text { wave }\end{array}$ & $\begin{array}{l}1980 \mathrm{~s} \\
\text { wave }\end{array}$ & $\begin{array}{l}1990 \mathrm{~s} \\
\text { wave }\end{array}$ & $\begin{array}{l}2000 \mathrm{~s} \\
\text { wave }\end{array}$ & $\begin{array}{l}\text { Pre- } \\
1970 \\
\end{array}$ & $\begin{array}{l}1970 \mathrm{~s} \\
\text { wave }\end{array}$ & $\begin{array}{l}1980 \mathrm{~s} \\
\text { wave }\end{array}$ & $\begin{array}{l}1990 \mathrm{~s} \\
\text { wave }\end{array}$ & $\begin{array}{l}2000 \mathrm{~s} \\
\text { wave }\end{array}$ \\
\hline 1964 & 1379 & & & & & 0.66 & & & & \\
\hline 1965 & 1500 & & & & & 0.67 & & & & \\
\hline 1966 & 1647 & & & & & 0.65 & & & & \\
\hline 1967 & 1792 & & & & & 0.69 & & & & \\
\hline 1968 & 1996 & & & & & 0.74 & & & & \\
\hline 1969 & 2440 & & & & & 0.74 & & & & \\
\hline 1970 & 2408 & 219 & & & & 0.59 & 0.62 & & & \\
\hline 1971 & 2370 & 449 & & & & 0.60 & 0.68 & & & \\
\hline 1972 & 2332 & 619 & & & & 0.66 & 0.73 & & & \\
\hline 1973 & 2290 & 805 & & & & 0.65 & 0.72 & & & \\
\hline 1974 & 2159 & 1181 & & & & 0.61 & 0.57 & & & \\
\hline 1975 & 2121 & 1594 & & & & 0.58 & 0.51 & & & \\
\hline 1976 & 2013 & 1678 & & & & 0.56 & 0.53 & & & \\
\hline 1977 & 1884 & 1731 & & & & 0.56 & 0.53 & & & \\
\hline 1978 & 1811 & 1815 & & & & 0.54 & 0.54 & & & \\
\hline 1979 & 1728 & 1822 & & & & 0.49 & 0.49 & & & \\
\hline 1980 & 1645 & 1727 & 180 & & & 0.52 & 0.51 & 0.60 & & \\
\hline 1981 & 1595 & 1604 & 391 & & & 0.45 & 0.50 & 0.51 & & \\
\hline 1982 & 1525 & 1526 & 583 & & & 0.36 & 0.45 & 0.35 & & \\
\hline 1983 & 1468 & 1432 & 971 & & & 0.41 & 0.42 & 0.35 & & \\
\hline 1984 & 1334 & 1337 & 1208 & & & 0.42 & 0.27 & 0.30 & & \\
\hline 1985 & 1246 & 1233 & 1391 & & & 0.38 & 0.28 & 0.19 & & \\
\hline 1986 & 1144 & 1156 & 1651 & & & 0.31 & 0.23 & 0.27 & & \\
\hline 1987 & 1117 & 1079 & 1981 & & & 0.43 & 0.41 & 0.35 & & \\
\hline 1988 & 951 & 957 & 1903 & & & 0.26 & 0.31 & 0.24 & & \\
\hline 1989 & 949 & 955 & 2097 & & & 0.22 & 0.28 & 0.23 & & \\
\hline 1990 & 905 & 920 & 1946 & 304 & & 0.14 & 0.17 & 0.11 & 0.07 & \\
\hline 1991 & 913 & 885 & 1837 & 602 & & 0.05 & 0.17 & 0.13 & 0.04 & \\
\hline 1992 & 891 & 877 & 1717 & 919 & & 0.11 & 0.24 & 0.12 & 0.06 & \\
\hline 1993 & 854 & 839 & 1613 & 1418 & & 0.10 & 0.15 & 0.13 & 0.06 & \\
\hline 1994 & 813 & 812 & 1462 & 1797 & & 0.23 & 0.22 & 0.10 & 0.08 & \\
\hline 1995 & 786 & 798 & 1398 & 2351 & & 0.10 & 0.30 & 0.09 & 0.06 & \\
\hline 1996 & 748 & 759 & 1275 & 3159 & & 0.21 & 0.24 & 0.08 & 0.04 & \\
\hline 1997 & 702 & 710 & 1161 & 3547 & & 0.11 & 0.23 & 0.03 & 0.02 & \\
\hline 1998 & 625 & 672 & 1059 & 3467 & & 0.06 & 0.19 & 0.06 & 0.00 & \\
\hline 1999 & 640 & 625 & 1009 & 4286 & & 0.09 & 0.28 & 0.03 & 0.00 & \\
\hline 2000 & 608 & 582 & 936 & 3676 & 705 & 0.05 & 0.09 & 0.02 & 0.01 & 0.04 \\
\hline
\end{tabular}




\begin{tabular}{lllllllllll}
2001 & 560 & 542 & 883 & 3295 & 980 & 0.14 & 0.13 & 0.03 & 0.01 & 0.01 \\
2002 & 556 & 521 & 811 & 2958 & 1069 & 0.12 & 0.07 & 0.05 & 0.00 & 0.01 \\
2003 & 544 & 496 & 774 & 2702 & 1271 & 0.27 & 0.23 & 0.03 & 0.01 & 0.00 \\
2004 & 513 & 468 & 721 & 2449 & 1493 & 0.17 & 0.34 & 0.12 & 0.02 & 0.00 \\
2005 & 484 & 443 & 679 & 2275 & 1766 & 0.07 & 0.23 & 0.07 & 0.02 & 0.00 \\
2006 & 460 & 430 & 632 & 2069 & 2072 & 0.30 & 0.05 & 0.09 & 0.01 & 0.00 \\
2007 & 420 & 391 & 596 & 1907 & 2323 & 0.14 & 0.14 & 0.05 & 0.00 & 0.00 \\
2008 & 418 & 391 & 557 & 1775 & 2404 & 0.01 & 0.01 & 0.01 & 0.00 & 0.00 \\
2009 & 412 & 387 & 545 & 1684 & 2471 & 0.17 & 0.21 & 0.00 & 0.01 & 0.01 \\
2010 & 391 & 372 & 512 & 1502 & 2458 & 0.09 & 0.13 & 0.02 & 0.01 & 0.00 \\
2011 & 369 & 351 & 475 & 1383 & 2498 & 0.05 & 0.17 & 0.03 & 0.00 & 0.01 \\
2012 & 374 & 342 & 455 & 1270 & 2645 & 0.10 & 0.26 & 0.00 & 0.00 & 0.00 \\
2013 & 363 & 336 & 429 & 1220 & 3011 & 0.14 & 0.23 & 0.00 & 0.00 & 0.00 \\
2014 & 312 & 291 & 318 & 928 & 2235 & 0.11 & 0.23 & 0.12 & 0.00 & 0.00 \\
\hline
\end{tabular}

This table reports the number of firm-year observations from the successive listing cohorts in each year from 1964 to 2014. All of the firms are divided into five listing cohorts in the following steps. The first year in which a firm's data are available in Compustat is referred to as the "listing year". All of the firms with a listing year before 1970 are classified as "pre-1970". The remaining firms listed in a common decade are referred to as a wave of newly-listed firms in the 1970s, 1980s, 1990s, and 2000s. The adjusted $\mathrm{R}^{2}$ from the Dechow (1994) model is based on the regression: $T A C C_{t}=\beta_{0}+\beta_{1} C F O_{t}+e_{t}$, which is estimated annually for each cohort. $T A C C_{t}$ is total accruals. $C F O_{t}$ is cash flows from operations. The sample includes 217,164 firm-year observations with non-missing $T A C C_{t}$ and $C F O_{t}$ from 1964 to 2014. Each year, all variables are Winsorized at 1 percent and 99 percent. 


\section{Table 7}

\section{Robustness tests: Time trend regressions of the adjusted $\mathbf{R}^{2}$ from the Dechow and Dichev (2002) model}

\begin{tabular}{|c|c|c|c|c|}
\hline & Test & $\begin{array}{c}b_{0} \\
(\mathrm{t}-\mathrm{stat})\end{array}$ & $\begin{array}{c}b_{1} \\
(\mathrm{t}-\mathrm{stat})\end{array}$ & Adj. $\mathrm{R}^{2}$ \\
\hline 1 & $\begin{array}{l}\text { Top } 1000 \text { firms each year in terms of } \\
\text { total assets }\end{array}$ & $\begin{array}{l}0.771 \\
(28.05)\end{array}$ & $\begin{array}{l}-0.013 \\
(-13.71)\end{array}$ & 0.792 \\
\hline 2 & $\begin{array}{l}\text { Alternative definitions of accruals and } \\
\text { cash flows in Richardson, Sloan, } \\
\text { Soliman, and Tuna (2005) }\end{array}$ & $\begin{array}{c}0.636 \\
(21.32)\end{array}$ & $\begin{array}{c}-0.010 \\
(-10.25)\end{array}$ & 0.808 \\
\hline 3 & $\begin{array}{l}\text { Expand the Dechow-Dichev model by } \\
\text { including CFO from } t-2 \text { to } t+2\end{array}$ & $\begin{array}{c}0.788 \\
(35.94)\end{array}$ & $\begin{array}{l}-0.017 \\
(-21.45)\end{array}$ & 0.905 \\
\hline 4 & $\begin{array}{l}\text { Expand the Dechow-Dichev model by } \\
\text { including CFO from } t-3 \text { to } t+3\end{array}$ & $\begin{array}{c}0.807 \\
(36.34)\end{array}$ & $\begin{array}{l}-0.017 \\
(-21.43)\end{array}$ & 0.909 \\
\hline 5 & $\begin{array}{l}\text { Regressions by industry: mean industry- } \\
\text { specific adjusted } \mathrm{R}^{2}\end{array}$ & $\begin{array}{c}0.744 \\
(44.25)\end{array}$ & $\begin{array}{c}-0.012 \\
(-20.99)\end{array}$ & 0.900 \\
\hline 6 & $\begin{array}{l}\text { Regressions by industry: median } \\
\text { industry-specific adjusted } \mathrm{R}^{2}\end{array}$ & $\begin{array}{c}0.776 \\
(38.09)\end{array}$ & $\begin{array}{c}-0.014 \\
(-19.90)\end{array}$ & 0.890 \\
\hline
\end{tabular}

The dependent variable is the adjusted $\mathrm{R}^{2}$ from the Dechow and Dichev (2002) model or its expanded version, a proxy for the association between accruals and cash flows. Time is the number of years since 1964.

Dechow-Dichev model: TACC $_{t}=\beta_{0}+\beta_{1} C F O_{t-1}+\beta_{2} C F O_{t}+\beta_{3} C F O_{t+1}+e_{t}$

Expanded Dechow-Dichev model in Test 1:

$$
\text { TACC }_{t}=\beta_{0}+\beta_{1} C_{F O} O_{t-2}+\beta_{2} C F O_{t-1}+\beta_{3} C_{F O}+\beta_{4} C F O_{t+1}+\beta_{5} C F O_{t+2}+e_{t}
$$

Expanded Dechow-Dichev model in Test 2:

$$
\text { TACC }_{t}=\beta_{0}+\beta_{1} \mathrm{CFO}_{t-3}+\beta_{2} \mathrm{CFO}_{t-2}+\beta_{3} \mathrm{CFO}_{t-1}+\beta_{4} \mathrm{CFO}_{t}+\beta_{5} \mathrm{CFO}_{t+1}+\beta_{6} \mathrm{CFO}_{t+2}+\beta_{7} \mathrm{CFO}_{t+3}+e_{t}
$$

where $T A C C_{t}$ is total accruals, and $C F O_{t}$ is cash flows from operations. In Test 4 , we use alternative definitions of accruals and cash flows in Richardson, Sloan, Soliman, and Tuna (2005). $T A C C_{t}$ is total accruals measured as changes in non-cash assets minus changes in liabilities scaled by average total assets. $C F O_{t}$ is cash flows measured as changes in cash plus net cash distributions to equity scaled by average total assets, where net cash distributions to equity equal to cash dividends plus stock repurchases less equity issuances. In Tests 5 and 6 , we run the Dechow and Dichev regression for each 2-digit SIC industry and each year, with a minimum number of 20 observations. Then we calculate the mean and median industry-specific adjusted $\mathrm{R}^{2}$ each year. Finally, we regress the mean and median industry-specific adjusted $\mathrm{R}^{2}$ on Time. The sample includes 159,932 firm-year observations with non-missing $T_{A C C}, C F O_{t-1}, C F O_{t}$ and $C F O_{t+1}$ from 1964 to 2013. Each year, all variables are Winsorized at 1 percent and 99 percent. T-statistics in parentheses are adjusted for Newey-West autocorrelations of three lags. 


\section{Table 8}

\section{Robustness tests: Time trend regressions of the adjusted $\mathbf{R}^{2}$ from the Dechow and Dichev (2002) model by sectors}

\begin{tabular}{|c|c|c|c|c|c|c|}
\hline Sector & 1 & 2 & 3 & 4 & 5 & 7 \\
\hline & $\begin{array}{c}\text { Agriculture \& } \\
\text { Mining }\end{array}$ & Manufacturing & Technology & $\begin{array}{c}\text { Transportation } \\
\text { \& Utilities }\end{array}$ & Retail & Services \\
\hline Intercept & $\begin{array}{l}0.549 \\
(0.67)\end{array}$ & $\begin{array}{l}1.222 \\
(1.03)\end{array}$ & $\begin{array}{l}2.459 \\
(3.08)\end{array}$ & $\begin{array}{l}-0.552 \\
(-0.35)\end{array}$ & $\begin{array}{l}-4.040 \\
(-1.08)\end{array}$ & $\begin{array}{l}1.452 \\
(1.10)\end{array}$ \\
\hline Time & $\begin{array}{l}-0.008 \\
(-3.68)\end{array}$ & $\begin{array}{l}-0.009 \\
(-2.15)\end{array}$ & $\begin{array}{l}-0.004 \\
(-1.48)\end{array}$ & $\begin{array}{l}-0.007 \\
(-4.19)\end{array}$ & $\begin{array}{l}-0.006 \\
(-6.08)\end{array}$ & $\begin{array}{l}-0.004 \\
(-1.32)\end{array}$ \\
\hline $\operatorname{Std}(\mathrm{CFO})$ & $\begin{array}{l}1.108 \\
(1.38)\end{array}$ & $\begin{array}{l}0.443 \\
(0.35)\end{array}$ & $\begin{array}{l}-0.264 \\
(-0.22)\end{array}$ & $\begin{array}{l}0.301 \\
(0.19)\end{array}$ & $\begin{array}{l}1.529 \\
(1.45)\end{array}$ & $\begin{array}{l}2.969 \\
(2.33)\end{array}$ \\
\hline Auto__CFO & $\begin{array}{l}-0.111 \\
(-1.07)\end{array}$ & $\begin{array}{l}-0.140 \\
(-1.13)\end{array}$ & $\begin{array}{l}0.097 \\
(0.66)\end{array}$ & $\begin{array}{l}0.036 \\
(0.26)\end{array}$ & $\begin{array}{l}-0.079 \\
(-1.07)\end{array}$ & $\begin{array}{l}0.217 \\
(1.57)\end{array}$ \\
\hline Std(OI-PTI) & $\begin{array}{l}-3.172 \\
(-3.20)\end{array}$ & $\begin{array}{l}-3.254 \\
(-2.28)\end{array}$ & $\begin{array}{l}-2.996 \\
(-2.79)\end{array}$ & $\begin{array}{l}1.391 \\
(1.26)\end{array}$ & $\begin{array}{l}-2.553 \\
(-1.65)\end{array}$ & $\begin{array}{l}-1.262 \\
(-1.38)\end{array}$ \\
\hline PctLoss & $\begin{array}{l}-0.497 \\
(-3.93)\end{array}$ & $\begin{array}{l}-0.739 \\
(-2.13)\end{array}$ & $\begin{array}{l}-0.288 \\
(-1.05)\end{array}$ & $\begin{array}{l}-1.747 \\
(-5.91)\end{array}$ & $\begin{array}{l}-0.598 \\
(-2.10)\end{array}$ & $\begin{array}{l}-1.082 \\
(-5.13)\end{array}$ \\
\hline $\begin{array}{l}\text { Adj.R }{ }^{2} \\
\text { (Dichev_Tang) }\end{array}$ & $\begin{array}{l}0.081 \\
(0.11)\end{array}$ & $\begin{array}{l}-0.631 \\
(-0.59)\end{array}$ & $\begin{array}{l}-1.170 \\
(-1.56)\end{array}$ & $\begin{array}{l}1.485 \\
(0.97)\end{array}$ & $\begin{array}{l}4.729 \\
(1.25)\end{array}$ & $\begin{array}{l}-0.502 \\
(-0.40)\end{array}$ \\
\hline SG\&A Intensity & $\begin{array}{l}0.273 \\
(0.77) \\
\end{array}$ & $\begin{array}{l}0.839 \\
(0.60) \\
\end{array}$ & $\begin{array}{l}-2.184 \\
(-2.92)\end{array}$ & $\begin{array}{l}-1.016 \\
(-1.34)\end{array}$ & $\begin{array}{l}0.066 \\
(0.05) \\
\end{array}$ & $\begin{array}{l}-1.519 \\
(-2.28)\end{array}$ \\
\hline Adj. $\mathrm{R}^{2}$ & 0.889 & 0.896 & 0.918 & 0.880 & 0.921 & 0.891 \\
\hline $\begin{array}{l}\text { \# of firm-year } \\
\text { observations }\end{array}$ & 16099 & 49459 & 27691 & 25925 & 20199 & 19254 \\
\hline
\end{tabular}

The dependent variable is the adjusted $\mathrm{R}^{2}$ from the Dechow-Dichev (2002) model, a proxy for the association between accruals and cash flows. Time is the number of years since 1964. Std(CFO) is the standard deviation of cash flows. Auto $\triangle C F O$ is the lag one autocorrelation of changes in cash flows. Std(OI-PTI) is the standard deviation of the difference between operating income after depreciation and pre-tax income, which proxies for the effect of onetime items and nonoperating income. PctLoss is the percentage of firms with negative earnings before extraordinary items. Adj. $R^{2}$ (Dichev_Tang) is the adjusted $\mathrm{R}^{2}$ from the Dichev-Tang (2008) model, a proxy for the match between revenue and expenses. $S G \& A$ Intensity is SG\&A intensity measured as selling, general, and administrative expenses scaled by total expenses, where total expenses are equal to sales minus earnings before extraordinary items.

Dechow-Dichev model: TACC $_{t}=\beta_{0}+\beta_{1} C F O_{t-1}+\beta_{2} C F O_{t}+\beta_{3} C F O_{t+1}+e_{t}$ where $T A C C_{t}$ is total accruals, and $C F O_{t}$ is cash flows from operations. The sample includes 159,932 firm-year observations with non-missing $T A C C_{t}, C F O_{t-1}, C F O_{t}$ and $C F O_{t+1}$ from 1964 to 2013. Each year, accruals and cash flow variables are Winsorized at 1 percent and 99 percent. Sectors are defined as follows, with two-digit SIC codes in parentheses: Agriculture and Mining $(1<=\mathrm{SIC}<=19)$, Manufacturing $(20<=\mathrm{SIC}<=34,37,39)$, Technology $(35,36,38)$, Transportation and Utilities $(40<=\mathrm{SIC}<=49)$, Retail $(50<=\mathrm{SIC}<=59)$, and Services $(70<=\mathrm{SIC}<=89)$. Tstatistics in parentheses are adjusted for Newey-West autocorrelations of three lags. 


\section{Table 9}

\section{Implications: The properties of residual accruals}

Panel A: Residual accruals from the levels Dechow model

\begin{tabular}{|c|c|c|c|}
\hline Dependent variable & Intercept & Time & Adj. $R^{2}$ \\
\hline $\begin{array}{l}\text { (1) Average residual accruals from pooled regression } \\
\text { minus average residual accruals from annual regressions }\end{array}$ & $\begin{array}{c}0.057 \\
(13.45)\end{array}$ & $\begin{array}{l}-0.0019 \\
(-13.12)\end{array}$ & 0.774 \\
\hline $\begin{array}{l}\text { (2) Average residual accruals from firm-specific regressions } \\
\text { minus average residual accruals from annual regressions }\end{array}$ & $\begin{array}{l}0.015 \\
(5.08)\end{array}$ & $\begin{array}{l}-0.0008 \\
(-7.61)\end{array}$ & 0.533 \\
\hline $\begin{array}{l}\text { (3) Annual std(residual accruals) from pooled regression } \\
\text { minus annual std(residual accruals) from annual regressions }\end{array}$ & $\begin{array}{c}0.027 \\
(22.38)\end{array}$ & $\begin{array}{l}-0.0007 \\
(-16.19)\end{array}$ & 0.839 \\
\hline $\begin{array}{l}\text { (4) Annual std(residual accruals) from firm-specific regressions } \\
\text { minus annual std(residual accruals) from annual regressions }\end{array}$ & $\begin{array}{l}-0.007 \\
(-5.39)\end{array}$ & $\begin{array}{c}-0.0004 \\
(-8.10)\end{array}$ & 0.564 \\
\hline
\end{tabular}

Panel B: Residual accruals from the Dechow-Dichev model

\begin{tabular}{lccc} 
Dependent variable & Intercept & Time & Adj. $\mathrm{R}^{2}$ \\
\hline $\begin{array}{l}\text { (1) Average residual accruals from pooled regression minus } \\
\text { average residual accruals from annual regressions }\end{array}$ & 0.046 & -0.0016 & \\
& $(12.97)$ & $(-13.03)$ & 0.775 \\
& 0.010 & -0.0005 & \\
& $(4.67)$ & $(-6.30)$ & 0.441 \\
$\begin{array}{l}\text { (2) Average residual accruals from firm-specific regressions } \\
\text { minus average residual accruals from annual regressions }\end{array}$ & 0.015 & -0.0004 & \\
& $(17.10)$ & $(-12.38)$ & 0.756 \\
$\begin{array}{l}\text { (3) Annual std(residual accruals) from pooled regression } \\
\text { minus annual std(residual accruals) from annual regressions }\end{array}$ & & \\
$\begin{array}{l}\text { (4) Annual std(residual accruals) from firm-specific regressions } \\
\text { minus annual std(residual accruals) from annual regressions }\end{array}$ & -0.008 & -0.0006 & \\
\hline
\end{tabular}

We estimate the Dechow or Dechow-Dichev model in three ways: annual regressions, pooled regression, and firmspecific regressions. Then each year, we calculate the average and standard deviation of residual accruals across firms under each regression specification. The dependent variables in this table are (1) average residual accruals from the pooled regression minus average residual accruals from annual regressions, (2) average residual accruals from firm-specific regressions minus average residual accruals from annual regressions, (3) the standard deviation of residual accruals from the pooled regression minus the standard deviation of residual accruals from annual regressions, and (4) the standard deviation of residual accruals from the firm-specific regressions minus the standard deviation of residual accruals from annual regressions. The independent variable is Time, measured as the number of years since 1964. The sample includes 217,164 firm-year observations with non-missing $T A C C_{t}$ and $C F O_{t}$ from 1964 to 2014 in Panel A and 159,932 firm-year observations with non-missing $T A C C_{t}, C F O_{t-1}, C F O_{t}$ and $C F O_{t+1}$ from 1964 to 2013 in Panel B. For firm-specific regressions, we require at least ten observations to run a regression.

Dechow model: $T A C C_{t}=\beta_{0}+\beta_{1} C F O_{t}+e_{t}$

Dechow-Dichev model: $T A C C_{t}=\beta_{0}+\beta_{1} C F O_{t-1}+\beta_{2} C F O_{t}+\beta_{3} C F O_{t+1}+e_{t}$ where $T A C C_{t}$ is total accruals. $C F O_{t}$ is cash flows from operations. Each year, accruals and cash flow variables are Winsorized at 1 percent and 99 percent. 